ORIGINAL RESEARCH ARTICLE

\title{
Bounding Boundaries: Building a Typology of Careers with the Concept of Boundary
}

\author{
Sébastien Dubois ${ }^{1 *}$ and Pierre Francois ${ }^{2}$ \\ 'NEOMA Business School, Mont Saint-Aignan, France \\ ${ }^{2} \mathrm{CNRS}$ Centre de Sociologie des Organisations/Sciences Po, Amélie, Paris
}

\begin{abstract}
The core idea of this paper is that the concept of boundary can help us to understand the social form careers take. The concept of boundary has informed much of the literature on careers. Scholars are now looking beyond the boundaryless/boundaried divide as the boundaryless argument has been convincingly contested theoretically and empirically. This is what we do in this article. It offers a definition of career boundaries which can be empirically tested as both objective and subjective construct along two dimensions: the existence of fixed career patterns and that of individual, shared, or collective awareness of these patterns. This leads us to build a six-case typology combining these two dimensions. To test the explanatory power of this theoretical framework, we use the original case of French poets. As poets do not work in stable organizations, we could expect erratic careers. We find that poets' careers are not erratic, but follow fixed patterns, structured by publishers and the pace of publications, with, respectively, shared and individual awareness of these patterns. We also find that similarly reputed poets tend to follow similar career patterns as they cross the same boundaries at a similar moment in their career. We end by discussing how our typology can help to understand careers, using examples from the literature from various professional settings.
\end{abstract}

Keywords: Career boundaries; Creative industries; Poetry; Career patterns; Awareness

Handling editor:Thomas Roulet; Received: 19 January 20 I9; Accepted: 14 March 2020; Published: I6 December 2020

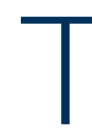

he core idea of this paper is that the concept of boundary - understood as the "physical, temporal, emotional, cognitive, and/or relational limits that define entities as separate from one another" (Ashforth, Kreiner, \& Fugate, 2000, p. 174) - can help us to understand the social form careers take. The concept of boundary has informed much of the scholarship on careers and organizations (Bird, Gunz, \& Arthur, 2002; Rodrigues \& Guest, 2014a). One leading idea has been that careers are becoming increasingly boundaryless (Arthur, 1994; Bird, 1994). The boundaryless theory can first denote a career moving "across the boundaries of separate employers" (Arthur, 1994, p. 296), as opposed to an organizational career comprising a series of organizational positions (Wilensky, I96I). Boundaryless career theory has been criticized for lacking both conceptual precision (Inkson, Gunz, Ganesh, \& Roper 2012) and empirical reality (Dries, Van Acker, \& Verbruggen, 2012; Rodrigues \& Guest, 20 I0), as boundaryless careers concern only a limited number of competitive workers, which may blur the fact that many careers remain organizational (Clarke, 2013; Kilduff \& Corley, 1999). Boundarylessness may thus be more a metaphor "aiming to highlight trends in contemporary careers than a fully developed theory" (Rodrigues \& Guest, 20 | 4b, p. 610). More recently, scholars have attempted to go beyond the boundaried/boundaryless divide (Arthur, 2014; Gunz, Peiperl, \& Tzabbar, 2007; Rodrigues \& Guest, 2014a, 2014b). As BudtzJørgensen, Johnsen and Sørensen (2019, p. 918) note "contemporary career development cannot be fully captured without new concepts that allow us to understand how boundaries are currently being reconfigured in work organizations." We cannot do this without taking into account one of the main insights of career conceptualization and investigation, i.e., that careers are both an objective and subjective construct (Becker, 1952; Budtz-Jørgensen et al., 2019). How then can we define a workable concept of career boundaries encompassing different kinds of career boundaries (organizational or not), while effectively bridging the subjective and objective dimensions of careers?

*Corresponding author: Sébastien Dubois, Email: sebastien.dubois@neoma-bs.fr 
We propose defining career boundaries on two related dimensions (Barley, 1989). The first, objective dimension, of career boundaries refers to the existence of fixed patterns that structure professional trajectories. The second, subjective dimension, of career boundaries is the awareness that actors have (or not) of these fixed patterns. This definition enables us to develop a transposable, effective typology of careers as well as the methodological apparatus necessary for empirical investigation. Our second major aim is to explore whether creative careers are bounded or, as they have often been described, boundaryless, probably because they are not organizational (Jones, 1996; Stjerne \& Svejenova, 20 16; Zwaan, ter Bogt, \& Raaijmakers, 20 I0). We empirically at creative industry careers boundaries by exploring what first structures creative fields, namely, reputation (Bourdieu, 1996; Menger, 1999; Peltoniemi, 2015). Our aim is then to discuss reputation as a new career boundary, which, to our knowledge, has not yet been investigated. Reputation in creative fields rests on collaborations between artists and 'gatekeepers' (publishers, art dealers, etc.) (Hirsch, 1972) able to disseminate artists' work to their audiences (the public, critics, and peers). Artists collaborate with these gatekeepers when, for instance, publishing a book. Having (or not) collaborations with more or less reputed gatekeepers thus determines artistic success (Giuffre, 1999). This suggests that for artistic careers collaborations with gatekeepers might constitute a boundary related to reputation-making.

To test these ideas, we have chosen the case of French contemporary poets. Poets are not salaried by publishers, but lead one-shot collaborations: their careers are not organizational, like most artistic workers (Menger, 1999). Publishers are the most powerful gatekeepers for poets (Sapiro, 2019). This leads us to explore whether collaborations with publishers structure poets' careers, and act as a career boundary. Following our definition, this raises two questions. Can we find objective fixed patterns in poets' careers, organized around their associations with publishers? If we do, are poets aware of these patterns? We show that poets' careers are not quite so unstructured as they might seem at first. Instead, they are shaped by reputation processes in which publishers, and publishers' reputations, play a central role, and where similarly reputed poets tend to follow similar careers paths.

We begin by discussing concepts of boundary and career boundary. From this, we deepen our theoretical analysis of career boundaries, ending with a usable and reproducible typology of career boundaries. We turn to artistic career boundaries to highlight why they are conducive to exploring career boundaries, before introducing our empirical design, data, and method. The next section exposes our findings, as we find two out of our five boundary types in French poets' careers, related to reputation building. We then consider all our boundary types in the discussion section, using both our results and existing literature. We conclude by suggesting new avenues for career research.

\section{Theoretical background}

\section{Boundaries}

Boundaries are commonly conceptualized as lines that circumscribe entities (Quick \& Feldman, 20|4; Tilly \& Tarrow, 2006), demarcating or categorizing organizations, occupations, or social groups (Ashforth et al., 2000). Abbott (1995b) argues that social entities do not predate boundaries, but rather that boundaries create social entities. This statement might seem counterintuitive. We often conceive that entities come first, as is the case with our human body. Our bodies have obvious boundaries, which derive from its physical existence: this is how we perceive (see, hear, etc.) the world around us. For Abbot, the process of constructing a social entity obeys a diametrically opposed logic: boundaries emerge and can sometimes engender the entities that they enclose. Boundaries are thus fixed elements of the social structure, but they are not set in stone. They result from a social process, a flux. They are not a fixed demarcation, as Langley et al. (2019) note and insist that our definition should not take boundaries for granted, but should rather account for their creation or transformation. In other words, it should take into account the history of boundary transformation within specific social contexts. As Hernes (2004, p. 10) put it, "boundary setting is intrinsic to the very process of organizing." We should distinguish between "symbolic" boundaries, which are "conceptual distinctions made by social actors to categorize objects, people, practices, and even time and space," and social boundaries, which are "objectified forms of social differences [...] revealed in stable behavioural patterns of association" (Lamont \& Molnar, 2002, p. 168). Boundaries are both objective and subjective constructs (Abbott, 1995a). They not only demarcate entities, but actors interpret their doing so. Actors can be right or wrong in understanding boundaries (Bourdieu, 1978). A crucial point is that actors can frame, manipulate, span, or move boundaries: this is 'boundary work' (Langley et al., 2019). Inkson et al. (2012) argue that boundaries have traditionally served three distinct roles: as constraints (restricting possibilities), as enablers (facilitating development), and as punctuators (structuring development). Boundaries appear not only as a source of legitimacy and self-protection and act as a tool to allow other things to happen because of their capacity to separate or bring particular people, objects, and ideas into new configurations.

\section{Career boundaries}

Careers provide a prime framework, in which to elaborate on the concept of boundary (Inkson et al., 20I2). Indeed, in the 
wake of the Chicago School of Sociology (Becker \& Strauss, 1956; Hughes, 1937), careers can be defined as a "stream of more or less identifiable positions, offices, statuses, and situations that serve as landmarks for gauging a person's movement through the social milieu" (Barley, 1989, p. 49). When shifting positions, actors cross the lines that separate the positions which succeed one another; this series of positions makes a career. Career boundaries are the lines actors cross when shifting positions. Careers are thus made of orderly related sequences of positions and boundary-crossing (Abbott \& Hrycak, 1990; Barley \& Tolbert, 1997; Dany, Louvel, \& Valette, 201 I). These changes of positions can be organizational, but they can also be a change in social status or knowledge domain (Lam, 2019). Workers' positions very rarely remain the same throughout their professional lives. As Gunz et al. (2007, p. 474) put it, "it is the nature of the boundaries crossed and the frequency of these movements from one side of fixed lines to another that give shape to careers. A career $[\ldots]$ becomes a sequence of boundary-crossings that are largely responsible for giving it its form."

Beyond the debate about organizational boundaries (Bagdadli \& Gianecchini, 2018; Rodrigues \& Guest, 2010), research has explored non-organizational career boundaries. For instance, education largely shapes careers even long after graduation (Bol, 20 I5; Bourdieu, 1978; Schworm et al., 20 17). Social capital and personal networks directly impact job searches, and thus shifts in positions (Granovetter, 1973). Career research has recently turned to cultural boundaries related to actors' values, knowledge, and perceptions (Lam, 2019), which have also been often overlooked (Staniland, Harris, \& Pringle, 2019). Cultural boundaries can derive from the social as well as the professional context (Dafou, 2018). This includes gender, race, culture, and religion (Essers \& Benschop, 2007). Hagan, Zatz, Arnold and Kay (199|) find that in the legal profession, women follow different career paths than men, which they call as the 'mommy track.' Race is also a boundary which determines career progress (Castilla, 2008). Ituma and Simpson (2009) find that not only gender but also ethnic allegiances shape information communication and technology (ICT) workers' careers in Nigeria, emphasizing the impact of the social and cultural context on career boundaries in a country where several ethnic groups live in conflict. The debate about the anonymous curriculum vitae demonstrates the power of these boundaries over careers, as well as the State policies intended to overcome these boundaries (Bóo, Rossi, \& Urzúa, 20 I3). Career boundaries can thus be imposed by 'gatekeepers' on job opportunities (King, Burke, \& Pemberton, 2005) or can be related to workers' preferences or constraints. Gubler, John and Crispin (2014) show that geographical preferences bound careers, resulting from social constraints and/or choices (home, family). Other preferences include job security (Dafou, 2018) and work-life balance, leading or constraining workers to make specific career choices like refusing a promotion or a new job, which would require them to move or would impact their personal life (Haar, Russo, Suñe, \& Ollier-Malaterre, 20l4). These individual choices are, of course, embedded in social contexts, such as the transformations of family life or the increasing importance given to the balance between private life and work (Henz \& Mills, 20 I5).

Like any form of boundary, career boundaries have both an objective and a subjective dimension. This echoes what the sociology of work and careers has long insisted on, depicting career as a Janus-like concept with two faces - objective and subjective (Becker, 1963; Becker \& Carper, 1956; Hughes, 1937). Indeed, actors themselves interpret the shifts in their career. Drawn again from Barley (1989) and the Chicago School of Sociology, the concept of career script has recently endeavored to bridge the objective and subjective dimensions of careers (Dany et al., 201 I ; Duberley, Cohen, \& Mallon, 2006), describing careers as a series of sequences, a 'story', or a script. Scripts are conceptualized as "plans for recurrent patterns of action that define, in observable terms, the essence of actors' roles" (Barley, 1989, p. 53). Dany et al. (201 I, pp. 5-6) define scripts as "the processes that drive individual choices and actions," and thus in the case of academic careers promotion scripts as "the rules and norms that individuals have in mind when they think of their careers." As Laudel, Bielick and Gläser (20।8) have argued, scholars using the concept of career script have focused on interpretive schemes enacted by individuals to the detriment of career patterns (Mallon, Duberley, \& Cohen, 2005). The concept remains ambiguous about the balance between career structures and cognitive schemes, and it is significant that these studies rely on qualitative data exclusively. Laudel et al. (2018, p. 9) themselves define "the script of an organizational career [as] an interpretive scheme which reflects sequences of organizational positions that are typically successful in achieving specific career goals." Moves seem here to be once again only organizational, and this paradoxically seems to undermine the power of organizations to shape careers, as in the case of painters whose careers were strictly constrained by the French Academy (Delacour \& Leca, 20 I I): painters' careers 'existed' out of the reach of individual painters, as a socially constructed path in a specific setting.

To avoid such confusions, we should analytically distinguish between the objective and subjective dimensions of careers. We argue that this is what the concept of boundary enables. We now discuss how this refinement of the concept of boundary helps not only to theorize careers further but also to develop a methodology to investigate career boundaries empirically. For instance, the concept should include time, as Rodrigues, Guest and Budjanovcanin (2016) suggest without resolving the problem. We thus aim in this article to frame a concept of career boundaries, which (I) would not be limited to organizational boundaries and (2) would fully integrate the 
objective and subjective dimension. To do so, we redefine the concept of career boundary as the existence (or not) of fixed career patterns, combined with actors' awareness (or not) of these patterns. We discuss this framework in the next section.

\section{Fixed patterns and awareness: A typology of career boundaries}

The challenge is to identify which discontinuities structure careers in a given profession, forming a boundary. We suggest that these discontinuities can be identified through the existence of fixed patterns organizing careers (Biemann, Zacher, \& Feldman, 2012). The idea of fixed patterns is that most careers follow preestablished, regular trajectories. As the Chicago School of Sociology has emphasized since the framing of the concept of career, we can speak of careers only if these fixed patterns do not concern only one person (Rodrigues et al., 20l6), but constitute a pathway that people follow in a given social world (Becker, 1963; Hughes, 1996). As Gunz, Lichtenstein and Long (2002, p. 65) note, "A career system is the pattern of movement between work roles and across boundaries," meaning here that workers cross boundaries when shifting from one work role (or position) to another. These fixed patterns, organized by the order and cadence at which the stages of a career are navigated, are the first criterion for the identification of career boundaries. To establish fixed patterns (say, a career pattern like 'State A-State B-State'), it is necessary to identify the discontinuity that appears between stages $A$ and $B$, then between $B$ and $C$, and thus to include time. We argue that fixed patterns are the objective facet of careers.

Careers also refer to actors' subjective experience of their trajectory, and the meaning they give to it. As Rodrigues et al. (2016) point out, boundaries can be more or less visible. Institutionalized boundaries may be evident to all, such as those regulating academia with the clear line of tenure (Court, 1998); others may be difficult for actors to identify, for instance, because they are illegitimate, as in the cases of race and gender (Castilla, 2008; Essig \& Soparnot, 2019). We thus need to measure the actors' awareness of these discontinuities. All this enables us to describe a boundary in terms of the actors' individual or collective awareness of fixed patterns governing their professional trajectory. More precisely, this awareness may be of three types: individual, shared, or collective. In the first case, some people may be aware of fixed patterns, whilst others (less lucid or well-informed) are not; some women may be aware that gender widely shapes careers, while others are not (Hagan et al., 1991). In this case, we speak of individual awareness. In the second case, assimilation within a professional group is such that almost all those in the group share the same vision of the normal stages of a career; here we speak of shared awareness. In the last case (collective awareness), the boundary has been institutionalized, so that actors cannot ignore the structuring of the different stages of their career: not only are the actors individually aware of the fixed patterns, but these patterns are also evident to all. Quite often, workers themselves contribute to shaping these boundaries through a professional association or a trade union: not only are all higher-education professors aware of fixed patterns based on the tenure system, but the academic community has contributed to the establishment of this career organization (Bedeian, Cavazos, Hunt, \& Jauch, 20 I0).

This leads us to draw a six-case typology, summarized in Table I. Our concept of boundaries combines the existence (or not) of fixed patterns, and the three possible forms of awareness (individual, shared, and collective).

We begin the presentation of our typology by briefly looking at what we call theoretical cases, since they are extremely rare or incoherent. The simplest situation is the absence of boundaries, where there is neither (individual, shared, or collective) boundary awareness nor a stable pattern. This is certainly an extreme case. We might suppose that very few cases exist where no fixed pattern appears and where workers move around in the social space as they wish (Gunz et al., 2007). If careers seem boundaryless, this may be because we do not use adequate criteria to analyze them. If, for instance, we attempt to look for a structure in artistic careers in terms of changes between organizations, the criterion is simply inappropriate. The combination of the absence of fixed patterns with collective awareness of these patterns is incoherent: it makes no sense that actors would have institutionalized patterns that would not exist. Our six-type typology is in reality a five-type one. We thus focus on these five remaining cases.

The unknown boundary designates situations where fixed patterns objectively structure actors' trajectories. Some actors may, of course, be aware of these fixed patterns, but most actors are not. The two next cases are when fixed patterns exist, and actors have shared awareness (a shared boundary) or collective awareness (an institutionalized boundary) of these patterns. A move from a shared boundary to an institutionalized boundary requires that institutionalized rules come to govern careers. The last two configurations (proto-boundary and symbolic boundary) correspond to what the Marxist tradition (Thompson, 2015) would have called 'false awareness.'This refers to actors who are convinced that certain social realities are established when they are not - in this case, that careers are structured by certain fixed patterns when, in fact, they are

Table I. Boundary types

\begin{tabular}{|c|c|c|c|}
\hline $\begin{array}{l}\text { Fixed } \\
\text { patterns }\end{array}$ & $\begin{array}{l}\text { Individual } \\
\text { awareness }\end{array}$ & $\begin{array}{l}\text { Shared } \\
\text { awareness }\end{array}$ & $\begin{array}{l}\text { Collective } \\
\text { awareness }\end{array}$ \\
\hline No & Proto-boundary & Symbolic boundary & Incoherent \\
\hline Yes & $\begin{array}{l}\text { Unknown } \\
\text { boundary }\end{array}$ & Shared boundary & $\begin{array}{l}\text { Institutionalizec } \\
\text { boundary }\end{array}$ \\
\hline
\end{tabular}


ordered by other principles of which they are unaware. The problem with analyzing such situations is to identify the conditions in which some actors develop this inadequate view of trajectories in their field, while others adopt a different, perhaps more appropriate, view. The first type, for which we use here Abbott's (Abbott, 1995a) term, proto-boundary, describes situations in which some actors (but not all) are convinced that careers are ordered in certain ways when this is not the case. The second configuration, when false awareness is shared by many of the actors in a field, is the symbolic boundary (Lamont \& Molnar, 2002). It does not mean that no other fixed patterns structure careers. As we have noted, careers rarely, if ever, have no boundaries. Rather, it means that actors do not see the fixed patterns: they use erroneous criteria and believe that a given pattern exists when it does not. Thus, careers can be, and often are, bounded by several intertwined boundaries, and our argument is that we have to identify and objectivize these boundaries to understand careers and professional settings.

\section{Careers and career boundaries in the creative industries}

\section{Careers, social context, and projects in the arts}

To test and discuss this framework, we have chosen the case of artistic careers. Artistic fields have been considered particularly appropriate for testing career boundaries. They are not structured around organizational boundaries, since artists are not employees of the cultural entrepreneurs who provide them with resources (Caves, 2000; Franssen \& Kuipers, 2013). This is why boundaryless career researchers have studied them extensively (Jones, 2001; Sgourev, 2013; Stjerne \& Svejenova, 20 16; Zwaan et al., 2010), often presenting creative careers as prime examples of boundarylessness. In our view, art worlds offer a prime opportunity to investigate whether non-organizational boundaries can structure careers.

Far from the cliché of the lonely artist at work, creating, independent from any social constraint, artistic careers are also embedded in a specific social context (Becker, 1984). Art worlds are social spaces organized around one specific activity (art), which bring together all the actors necessary to produce art along a specific division of labor. Poets, for instance, "depend on printers, editors and publishers to circulate their work" (Becker, 1984, p. 21 ). Artistic production depends on a given social and economic setting, which, in turn, shapes artistic careers. Apollinaire or Picasso would not even have been imaginable in the Renaissance. At the time, painting had to respect the Aristotelian doctrine of mimesis as the imitation of nature meant praising God, His creation, and the king whose power derived from God. Artistic careers were subject to the patronage system in France and beyond (McClellan, 1993). Similarly, poets and writers had long been 'civil servants' to the nobility and the king (Preisig, 2007) in France and in other European countries (Pleij, 2002). Technology is another example of why artistic careers are rooted in a social context, far from the lonely artist cliché as emphasized by Becker.The invention of printing in the late I 5 th century transformed the literary field allowing texts to circulate much more easily for a wider audience (Rigolot, 2002). In this perspective, scholars have shown that artistic careers have shifted from a patronage or academic organization to an entrepreneurial one in line with the transformations of modern capitalist societies, when artwork became goods priced on a market (Wijnberg \& Gemser, 2000). In France, the French Revolution put an end to the patronage system (Heinich, 2005), and the French Académie slowly declined (in England too, see Hoock, 2003). In the 19th century, the arts turned to a market-based organization within a capitalist society (Delacour \& Leca, 20l I; White \& White, 1992). Market-based artistic careers were not necessarily entrepreneurial, as in the motion picture industry, where artists were first salaried in the Fordist organization of the studios (Storper, 1989). However, the growing demand for innovation and the vertical disintegration of cultural industries led to flexible careers based on project management, as in the film industry (Jones, 1996; Neale \& Smith, 2013; Petit, 2012). Artistic careers became entrepreneurial not only in the film industry but also in the visual arts (Moulin, 2003) and literature, where not only authors but also editors increasingly work independently and are paid on copyright (Sapiro, 2003). In this market-based organization, the vast majority of artists navigate across organizations without secure, salaried contracts (Menger, 1999), including visual artists working with art dealers (Giuffre, 1999; Preece \& Kerrigan, 20I5), writers with publishers (Franssen \& Kuipers, 20I5), and cinema professionals with producers (Bielby \& Bielby, 1999). Artistic careers are made up of sequences which are not organizational. What then can make artists move from one sequence to another?

\section{Artistic careers and reputation}

An artist's main asset is the social recognition of his or her work (Becker, 1984; Bourdieu, 1996; Delacour \& Leca, 201 I). This suggests that the most striking boundaries in artistic careers should be related to reputational processes: reputation is what makes artists move from one sequence to another, from debutant to consecrated artist. Using a conceptual distinction inspired by Becker (1984), Lang and Lang (1988) argued that the difference between recognition and renown shapes artistic careers: the former referring to reputation in an art world, the latter to the extension of reputation to wider social circles, in keeping with the image of concentric circles through which artists move (Bowness, 1989). Reputation is a signal of quality, a perception based on the assessment of past works (Bitektine, 20 I I). It is 
subjective and operates only when shared by a community (Lang \& Lang, 2002). It then acts as a social fact that structures artistic careers (see, in various artistic fields, Dowd \& Pinheiro, 20 I3; Rosengren, 1985; Verboord, 201 I), yielding social recognition, if not financial and even political power, as in the cases of Neruda, Zola, and Hugo (Durand, 2005). As Becker (1984) points out, success depends on artists' integration in art worlds. From 'integrated professional' to 'mavericks,' reputation results from the interaction of many actors (Becker, 1984), including those who have the power to consecrate artists (publishers, art dealers, critics, art or literary historians, etc.). Artists, therefore, do not move freely in their social spaces. Their careers depend on other actors like publishers for writers (Childress, Rawlings, \& Moeran, 2017) or art dealers for visual artists, whose professional networks change when their reputations grow (Giuffre, 1999). The capacity of artists to produce a consistent abundance of work strengthens their position in art worlds, because a steady presence in artistic production keeps generating interest in an artist. It captures the attention of critics, collectors, or readers. Picasso (Sgourev, 2013), Hugo (Durand, 2005), and Andy Warhol (Hewer, Brownlie, \& Kerrigan, 2013) are examples of such artists. This suggests that artistic careers may be boundaried by the nature and frequency of their interactions with instances of consecration. This is what we will now empirically test in the case of poets, trying to explore whether poets' careers are structured by such fixed patterns, and whether poets are or are not aware of these patterns.

\section{Data and method}

\section{Empirical design: Poets' careers}

We chose poetry careers not only because they are not organizational, like many in creative industries, but also because poetry is located in the pure pole of the literary field, meaning that aesthetic logics dominate economic ones, and that economic success derives from artistic recognition (Bourdieu, 1996). Unlike the visual arts (Preece \& Kerrigan, 2015) or the novel (Cnossen, Dekker, \& Taskin, 2017), poetry largely ignores the usual tension between art and money (Peltoniemi, 2015). Sales remain poor, with few exceptions (Author, 2006). Moreover, very few French poets have immediate commercial success as novelists, like Houellebecq (Cnossen et al., 2017). Aesthetic recognition can bring money although very late in a career (Deguy, 1986). The best-selling 20th century poet, Apollinaire, sold 213 copies of his masterwork 'Alcools' upon its release in 1913. It now sells millions. Poets' careers consist of single-contract publications with publishers or magazines, and poetry events. Poets thus have a 'professional career' (Boschetti, 200I; Craig, 2007a). They develop a reputation during their careers, do earn money from poetry (even though it is usually not enough to make a living), and publish with professional publishers. Similarly, critics, public bodies involved in poetry, and booksellers who are active in poetry are also professionals. Most poets have a second job (Craig, 2007a), often related to their literary activity, like teaching or work in the cultural sector (editors, librarians, and cultural institutions' managers). Others hold important positions as publishers or editors for literature, thus being gatekeepers (Hirsch, 1972).

Publishers are a prime instance of consecration for poets (Boschetti, 200 I), who build a coherent lifetime oeuvre rather than a series of books (Vercier \& Viart, 2005). As Sapiro (2019, pp. 105-107) notes, "publishers still play the key role of gatekeepers into the literary field [...] Publishing with a professional and recognized publisher is indeed a condition for achieving both symbolic and professional recognition." The importance of publishers dates back to the early 19th century. Ladvocat was the major publisher of Romantics such as Hugo, Chateaubriand, and Gautier. At the time, publishing at Ladvocat was a signal of literary quality (Durand \& Glinoer, 2008). This trend increased with the development of new literary publishers like Gallimard in the early 20th century, who had more economic and consecrating power than their 19th century counterparts (Simonin, 1998).' The dominant literary publishers have remained the same since that period (Bourdieu, 1999), widely contributing to the shaping of literary reputations (Mounin, 1962; Sapiro, 2016; Simonin, 1998). According to the rules of the Centre National du Livre (CNL, the French State agency for literature and main funding body for French writers), poets can obtain awards or publicly funded grants only if they have worked with professional publishers. Poets thus need to strengthen their collaboration with major publishers, as do artists with art dealers (Preece \& Kerrigan, 20I5). Are poets' careers boundaried by reputation processes, and more precisely, by poets' relationships with publishers? Can we find fixed patterns in poets' careers, and are poets aware of these patterns? Our empirical design will allow us to discuss our typology and whether reputation can act as a non-organizational career boundary.

\section{Qualitative data and method}

To answer these questions, we use qualitative and quantitative data in the case of French contemporary poets. We base our qualitative data on an in-depth exploration of abundantly available secondary sources, as poets provide numerous reflexive and biographical accounts about poetry and their own experience as poets (e.g., Collot, 2019; Deguy, 1988; Di Manno, 1998;

\footnotetext{
Many publishers of the early 19th century went bankrupt (including Ladvocat), whereas Gallimard or later Le Seuil has consolidated their position in the literary field since their creation in 1909 and 1935, respectively. This fact provides evidence that (some) publishers are now stronger than they were a century ago. Gallimard's long existence is one of its key assets as a publishing house (Bourdieu, 1999).
} 
Forest, 1995), as well as on our own insider knowledge. ${ }^{2}$ In addition, we led 20 semi-structured interviews of poetry actors, including poets, and also booksellers and official poetry institutions, as they play an important role in poets' careers, funding both poets and publishers. We selected a range of interviewees (see the detailed list of interviews in Appendix I) with different $(1)$ roles in poetry (poets, publishers, editors, and booksellers) and (2) aesthetic orientations, as these are crucial in poetry, especially the 'classical' and 'experimental' divide (Collot, 2000). We used semi-structured interview guides, including open questions (McAlearney, 2006). These interviews lasted 90 min on average and took place between 2003 and 2005. We asked interviewees to develop their view of poetry and poetry careers, and to reconstruct their social trajectories (Bernard \& Barbosa, 2016) in the world of poetry. Table 2 details the list of our interviewees.

We transcribed all the interviews and then coded emerging themes in each transcript, to compare answers using thematic tables. Three prominent themes arose from the interviews: the diffusion of poetry, the relative role and importance of actors (poets, publishers, and booksellers), and the social trajectories of poets.

\section{Quantitative data and method}

To assess more systematically how poetry careers are structured, we use quantitative data. We first did a survey of the sales of 42 prominent contemporary poetry books published over the last 20 years and whose figures were available on the professional database Edistat. ${ }^{3}$ These estimates of sales, widely used by professionals, enable us to draw conclusions. To determine poets' publishing patterns, we used a database of 150 French poets born between 1899 and 1970, and who have been active since 1945. We built this initial list by recording all poets in the biographical database of the two main poetry institutions (Printemps des Poètes and centre international de poésie, Marseille), to which we added those mentioned in 13 anthologies of contemporary poetry (see Appendix I for the list of these anthologies). After drawing up our initial list, we measured poets' reputations by building an index using a set of weighted criteria (number of books released by large, medium, and small publishers, literary awards, and number of $\mathrm{PhD}$ theses devoted to the author), presence in the two main contemporary monographic poetry collections, and committee membership of poetry institutions (see Appendix | for the detailed weighting of this index). We retained the 150 poets with the best reputation scores and collected bio-bibliographical

\footnotetext{
2. One of the authors is a poet.

3. See https://www.edistat.com/. The database is professional and not free. It provides estimated sales figures based on a panel of booksellers (including specialized cultural supermarkets such as the FNAC and supermarkets), but only since the early 2000s.
}

Table 2. Interviewees

\begin{tabular}{|c|c|}
\hline Occupation & Date \\
\hline Poet & September 20, 2004 \\
\hline Poet, magazine editor & June 16, 2005 \\
\hline $\begin{array}{l}\text { Poet, editor of a paperback poetry } \\
\text { collection }\end{array}$ & February 8, 2005 \\
\hline Bookseller & September 9, 2003 (a) \\
\hline Bookseller & September 20, 2003 \\
\hline Bookseller & September 9, 2003 (b) \\
\hline Bookseller & December 14, 2004 \\
\hline Director of a state poetry institution & November 23, 2004 \\
\hline Poet & March 25, 2004 \\
\hline Ministry of Culture & October 21, 2004 \\
\hline $\begin{array}{l}\text { Centre National du Livre } \\
\text { Head of the Poetry and Theatre } \\
\text { Department }\end{array}$ & April 28, 2003 \\
\hline Director, Regional Book Office & November 4, 2003 \\
\hline Poet, publisher & October 21, 2003 \\
\hline Poet, editor & October 19, 2005 \\
\hline $\begin{array}{l}\text { Poet, webmaster of one of the most } \\
\text { read poetry websites }\end{array}$ & November 15, 2004 \\
\hline Poet, publisher & September 6, 2005 \\
\hline Poet, publisher & April 5, 2004 \\
\hline Poet & April 23, 2004 \\
\hline Poet & May 17, 2005 \\
\hline Poet and editor & December 17, 2005 \\
\hline
\end{tabular}

information on them. As poetry careers are very long, some poets are old, having been born at the beginning of the 20th century but still active in the 1990s and 2000s. Note that for only $11 \%$ are literature their primary occupation. This is also true for novelists, playwrights, and poets able to make a living through workshops, readings, or grants. The vast majority have a second job, mainly in education or in the cultural sectors (editors, librarians, curators, etc.), as summarized in Figure I.

We reconstructed their publishing careers, taking into account the type of publication (poetry, plays, essays, or fiction), publishers, publication dates, and, when applicable, coauthors. To identify their publishing trajectory, we divided publications into six categories using publisher reputation (major, midrange, and minor) and publication type (poetry or non-poetry). Our method is thus prosopographical, following leading studies in the field of literary careers (Lunden, Ekelund, \& Blom, 2002; Rosengren, 1985; Sapiro, 1998). We ranked publishers in line with Bourdieu (1999), who evaluates them using 12 criteria (including turnover, distribution, size, age, literary awards, best-sellers, and location). Using the same criteria, we added a number of small, specialized publishers that Bourdieu does not include, but which play an important role in contemporary poetry. To further assess poets' reputation, we counted the number of mentions of each poet in the Modern Language 


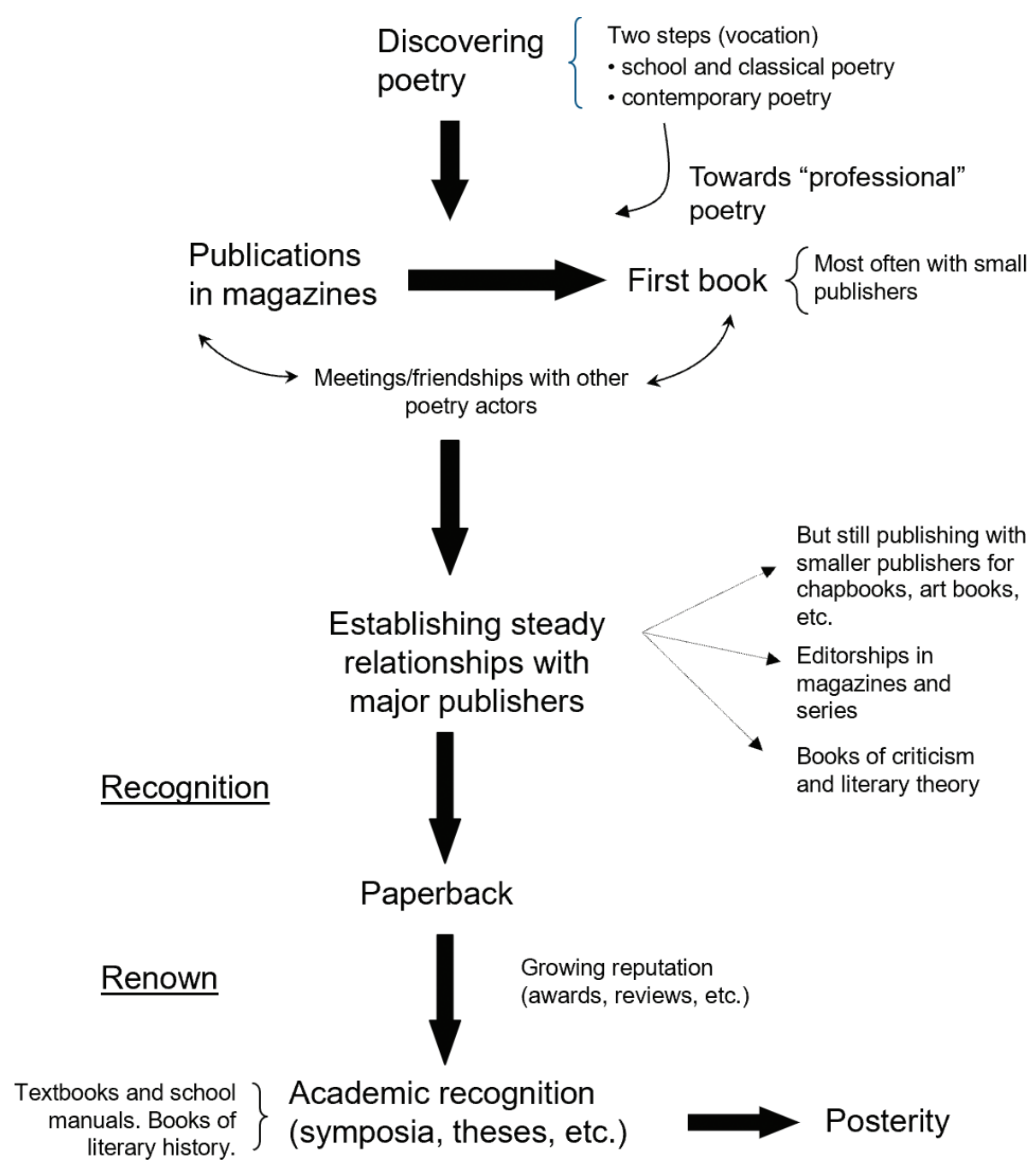

Figure I. Second jobs of poets

Association (MLA) database, which indexes literary critiques (critical consecration), and the number of theses written or being written on the poet using the ABES (Agence Bibliographique de l'Enseignement Supérieur) database (academic consecration). Last, we recorded whether or not the poet has been awarded the most prestigious French poetry prize (Grand Prix de la Poésie), and whether or not the poet has been included in the most prestigious monograph series about poets (Poètes d'aujourd'hui).

Studying non-apparent boundaries requires quite sophisticated tools to identify patterns that are not initially obvious. Quantitative methods are more suitable to isolate fixed patterns, because it is very difficult to study large groups using qualitative methods (Higgins \& Dillon, 2007). Similarly, the quantitative indicators most often used to study fixed trajectories, such as staff turnover (Donnelly, 2008; Ituma \& Simpson, 2009), are themselves too rudimentary to fully grasp the diversity of contemporary career paths. To measure the stability of the patterns that emerge from contemporary poets' trajectories, we used sequence analysis methods and, in particular, optimal matching. Indeed, as Abbott and Tsay (2000, p. 17I) state, "the chief strength of optimal matching is its ability to directly measure sequence resemblance." The basic principle of optimal matching analysis (OMA) is to calculate differences between individual trajectories, in order to cluster them (Lesnard, 2006). We used the open source statistical software R, and the 'TraMineR' and 'cluster' R packages (see Appendix 2 for more details).

OMA first needs to build individual trajectories as a series of sequences, here those of poets. To do so, we reconstructed poets' publishing careers annually using the criteria suggested earlier: publishers' reputation, type of publication (poetry or fiction/essay), format (paperback/hardcover), and the pace of 
publication (including silence), annually. This leads us to distinguish nine different publishing states (see Appendix 2 and Figure 2). Each year of a poet's activity corresponds to a state. The career of a poet thus consists of a succession of states: each poet can be identified by a more or less long sequence of publishing states. These sequences should reveal stable patterns in the publishing trajectories of contemporary poets. The average entropy score for their trajectories is high (see Appendix 2 for more details): on a scale of 0 (absolute trajectory stability) to I (completely chaotic trajectories), it is 0.527. This score indicates the irregularity of these trajectories and thus the difficulty of identifying shared, stable patterns without adequate systematic tools.

One of the goals of sequence analysis is to measure the homogeneity of the different trajectories (sequences) by creating trajectory classes or clusters. The proximity or distance between the different sequences is measured, and the sequences are then distributed to obtain the minimal distance between them within each class and the maximal distance between the classes. To make these comparisons, we need a 'centre of gravity', a reference trajectory, within each class. To define the reference trajectory, we used the medoid method. It consists of identifying the sequence closest to all the other sequences in a given cluster. As Aasve, Betti, Mazzuco, and Mencarini (2007, p. 379) explain, "Medoids enable us to present results in a way that is usually reserved for qualitative studies, in which single cases are used to illuminate findings (e.g., Moen \& Orrange, 2002). [...] By using the medoid method, we can compute the minimum, maximum and average distances within a cluster. This is an important feature, because the dispersion tells us whether any given cluster is highly heterogeneous, or highly homogeneous. Obviously, a homogeneous cluster contains very similar sequences (i.e., similar to the ideal-typical medoid), whereas a high dispersion suggests that sequences within the cluster are heterogeneous." OMA is thus particularly appropriate for precisely measuring the variability of trajectories and for revealing stable trajectory patterns.

\section{Findings}

\section{Poets' careers as stages shaped by reputation}

There are no poetry 'schools,' unlike those so important for visual artists (Becker, 1984) and musicians (Menger, 200I). Poets engage in a poetry career after a long apprenticeship through reading and interacting with other poets or intellectuals to learn poet conventions (Craig, 2007b; Dubois, 201 I). As a poet and magazine editor says:

I started reading very young. At school A (another poet) was my closest friend [...] we met again later in Paris, and launched a magazine... and yes, yes, I had two teachers, including first Mr. Paul $X$ in [a small provincial town in the Alps]. I studied modern literature and I wanted to be a writer. Or musician. After, a little more realistic with age, I wanted to be publisher or journalist. But always a writer (interview, June 6, 2005).

Other interviews as well as poets' biographical accounts (Stéfan, 2005) tell similar stories, to the extent that one poet and editor, speaking of the role first of professors and later of a famous poet who introduced him in the poetry world, say "To get back to your question, my beginnings in writing are so

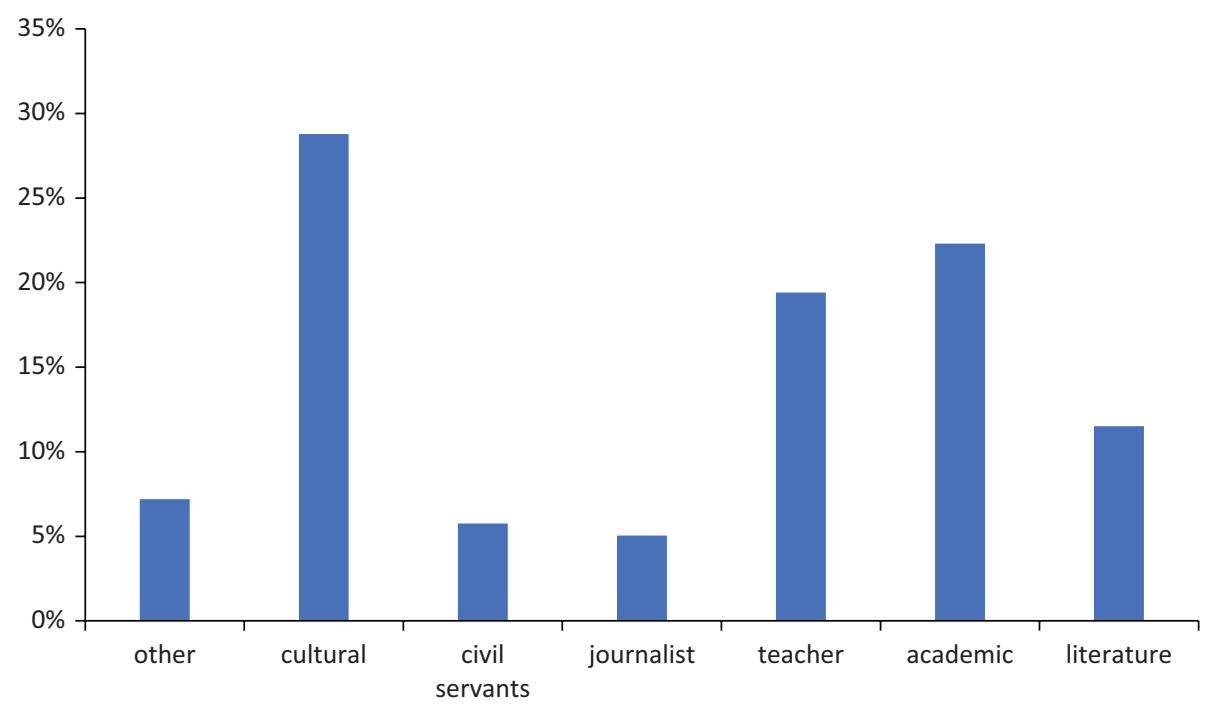

Figure 2. State distribution among the OMA classes of poets 
dull they'd make you weep" (interview, poet and editor, February 8, 2005). As literary magazines represent a smaller investment than a book; poets generally start by publishing in magazines, as this poet and webmaster acknowledges, explaining how it was 'vital' for him to be published in one of the leading experimental poetry magazines in the early 1970s (interview, November 15, 2004). For the same reason, their first book tends to be with a small publisher, who will take risks that major publishers would be reluctant to take (Simonin, 1998). The best reputed poets from our database, like Roubaud, Deguy, Bonnefoy and Jaccottet, were taken on by small publishers for their first books, before being published by major publishers such as Gallimard or Le Seuil. Only 19.8\% of poets from our sample published their first book of poetry with a major publisher.

The average age of first publication illustrates these steps. Poets reach their first printing with a major publisher on average at the age of 39 years old. One very important step is to publish in paperback, which will sell much better. Our survey of prominent contemporary poetry books shows that paperback editions sell 15,098 copies on average, peaking at 163,172, whereas standard editions sell 1,673 copies on average, peaking at 2,098. When poets are published in a paperback collection, their reputation rises and they are likely to be offered more opportunities, illustrating how the Matthew effect (Merton, 1968) also operates in poetry. Sales are boosted by renown, notably by inclusion in academic programs, as in the case of Bonnefoy and Jaccottet, the only two contemporary poets (now over 90) to have sold more than 80,000 copies, both of them in paperback. Interestingly, writers known first as novelists who have also published poems sell less in poetry than consecrated poets do. Houellebecq is such an example: his sales remain notably inferior to those of Bonnefoy and Jaccottet. ${ }^{5}$ Paperback books have much better distribution, as the editor of a paperback series states:

That's precisely the role of this collection. It takes an author and gives him a certain audience. If it's to sell I,200 copies, he can do that with Mercure [a smaller publisher and a subsidiary of Gallimard]. If it's to sell 1,700 copies in paperback, it makes no sense. Once again, I'm not obsessed with the numbers. I'm obsessed with the efficiency of including given contemporary authors in this collection (interview, February 8, 2005).

Paperback publication tends to happen late in a career. Jaccottet and Bonnefoy were the youngest to publish in paperback, at ages 46 and 47, respectively. In our sample, the average age of publication in paperback is 60 years old. The other very

\footnotetext{
4. Edistat database.

5. According to the professional Edistat database, Houellebecq's volume of poetry in the poetry paperback series Poésie Gallimard sold around I3,000 copies, whereas Bonnefoy and Jaccottet have sold respectively more than 150,000 copies and more than 80,000 copies in the same series.
}

prestigious series is La Pléiade (Gallimard). It is known as the 'Rolls Royce' of the French book market and has published since 1939, only 14 writers during their lifetime, including three poets born after 1900, namely, Char, Perse, and Jaccottet. They were all older than 75 at the time of printing. This also means that publishers have a financial interest in supporting (for a relatively small investment) poets whose work might be profitable when they enter the literary pantheon, like Perse or Char for Gallimard. Academic consecration is crucial and comes very late, as the education system tends to be conservative and includes few living poets (Maulpoix, 200I). In our sample, the first PhD thesis on a poet's work happens on average at the age of 68. This sketch of poets' careers can be summed up as sequences across various stages corresponding to the rise in reputation (see Figure 3), emphasizing the role of publishers.

Figure 3 illustrates that poets' careers are not unstructured, but instead are boundaried. Publishing a first book, having a first book at a major publisher and later in paperback are stages structuring poetry careers, and act as a boundary. Indeed, poets then hold a new position: that of a poet published at a professional publisher for the first time making him a 'professional' poet (Craig, 2007a), or later that of a poet published in paperback. Each of these steps corresponds to new associations with publishers, and to a rise in poets' reputation. Their relationships with publishers are thus crucial, from small to major publishers and those with paperback collections. Indeed, publishing trajectories are punctuated by awards, criticism, and academic consecration. However, the only long-term professional relations poets may have this with publishers. Awards are one-time events. Poetry magazines remain confidential and often ephemeral (Gleize, 2003). Readings are opportunities for poets, but do not lead to long-term engagements with any organization (Craig \& Dubois, 2010). The reputation of a publisher acts as a signal of literary quality (Franssen, 2015), and publishing books remains the main way to build reputation, even when poets do a lot of readings, as the following poet acknowledges:

Well, if a book can bring you a $€ 300$ advance and if it is a little visible, I don't have too much to complain about. I always get some press, some publicity ... and that can bring you 15, 20, maybe 30 readings. But then a reading, on the other hand, will pay between $€ 200$ and $€ 500$. So, the book itself is a loss leader, to speak like marketers ... [one of his books] brought me much, much more. The anthology: enormously, along with conferences (interview, poet and magazine editor, September 20, 2004).

This means that if we were to find fixed patterns in poets' careers, these must be structured first by their relationships with publishers. Four criteria shape the relationships between poets and publishers, and thus poets' careers: (I) the publisher's reputation, (2) the series in which the book is published 

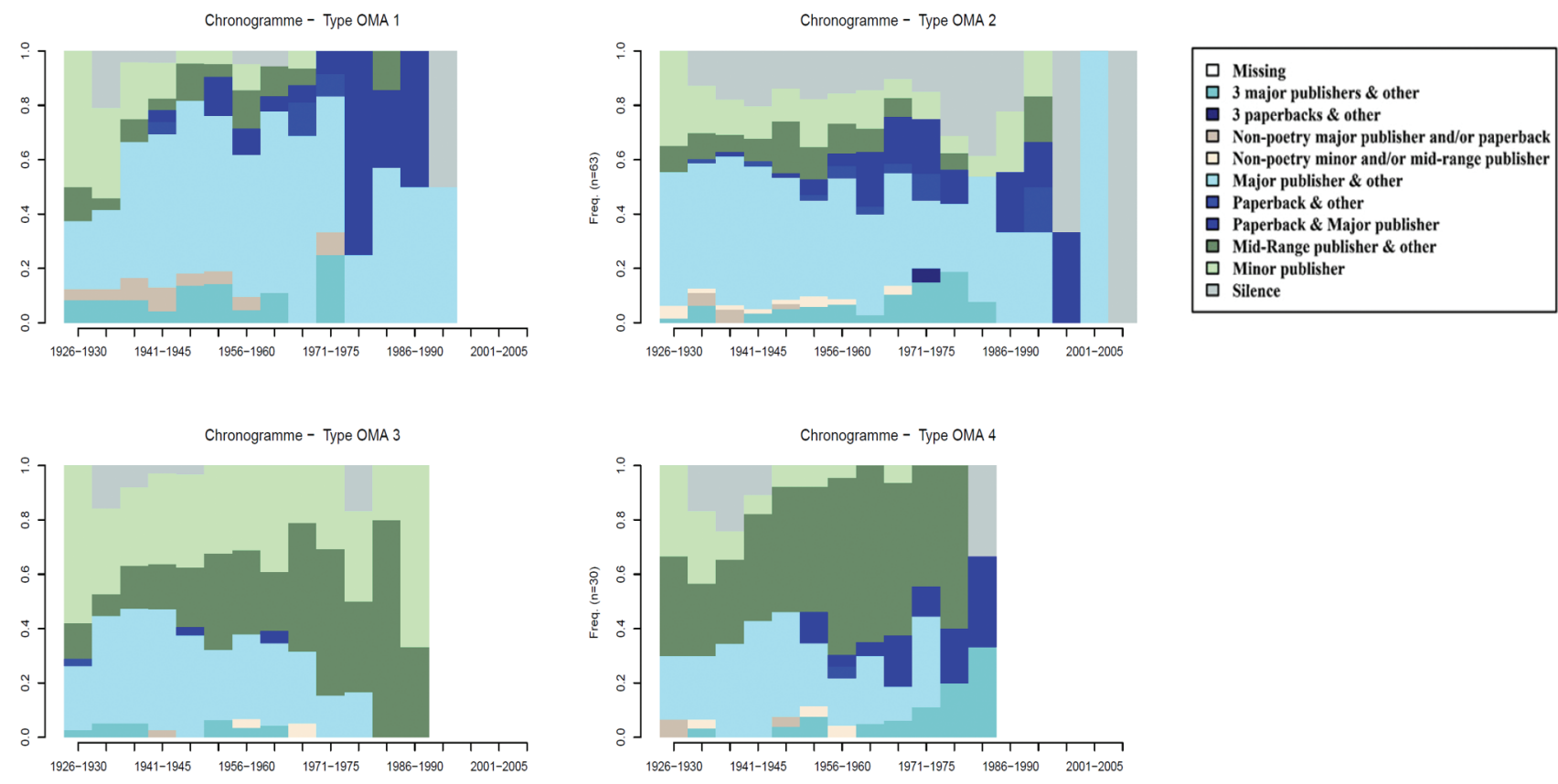

Figure 3. The 'ideal' career of a consecrated poet

(paperback or standard), (3) the literary genre (poetry, essay, and fiction), and (4) the rate of publication.

\section{Fixed patterns in poets' careers}

Our OMA results show that poets' careers do follow fixed patterns, with publishers acting as a boundary. Poets' trajectories cluster into four classes (Figure 2). Four typical career patterns emerge from our data structured around poets' relations with publishers. These four classes are only moderately dispersed around the medoid. The average distance from the medoid in each class is 1.5-2.5 times less than the average distance between the trajectories in the whole population (which is 0.44) and, in three out of four cases, the maximum distance from the medoid is approximately the same as the average distance between trajectories within the overall population (Table 3). In addition, again in three out of four cases, more than $80 \%$ of the trajectories in a given class are closer to the medoid of their class than to that of another class. Within each class, we find a stable pattern, which acts as a focal point around which the trajectories of a given class converge to greater or lesser degrees - rather than as a mandatory sequence that poets must follow.

The chronograms demonstrate that Types I and 2 poets spend much more time with major publishers and paperback publications than Types 3 and 4. Type I stands out from the others due to the length of time spent in the 'major publisher' state. The length of time spent in the paperback state also differentiates Type I from the others (see Table 4).
Table 3. Distance from medoids

\begin{tabular}{|c|c|c|c|c|c|}
\hline & All & $\begin{array}{c}\text { Class } \\
\text { । }\end{array}$ & $\begin{array}{c}\text { Class } \\
2\end{array}$ & $\begin{array}{c}\text { Class } \\
3\end{array}$ & $\begin{array}{c}\text { Class } \\
4\end{array}$ \\
\hline Class size* & 150 & 33 & 41 & 58 & 18 \\
\hline Average distance from medoid, intra-class & 0.31 & 0.19 & 0.28 & 0.28 & 0.3 \\
\hline Maximal distance from medoid, intra-class & 0.71 & 0.4 & 0.47 & 0.45 & 0.53 \\
\hline$\%$ of closest medoids from other classes & 0.27 & 0.15 & 0.15 & 0.5 & 0.11 \\
\hline
\end{tabular}

*All tests: $p<0.05$

Table 4. Average time spent in each state

\begin{tabular}{lccccc}
\hline & All & Class I & Class 2 & Class 3 & Class 4 \\
\hline Minor & 6.27 & $3.54 *$ & 5.36 & $9.03^{*}$ & $4.44 *$ \\
Midrange & 4.1 & $2.87 *$ & 4.34 & $5.5 *$ & $1.1 *$ \\
Major & 6.08 & $4.27 *$ & $8.3 *$ & 5.2 & $18.7 *$ \\
Paperback & 0.6 & $0.18^{*}$ & 0.85 & $0.18^{*}$ & $2.11^{*}$ \\
Silence & 23.34 & $10.51 *$ & $29.13^{*}$ & $20.25 *$ & $43.6 *$ \\
\hline
\end{tabular}

*The $p$-value from the two-tailed Student significance test is 0.05 .

In this Type I class, dominant positions either predominate in absolute terms (major publisher) or feature more than in other classes (paperback). Type 2 is close to Type I, but with the important difference that Type 2 poets are often more silent than Type 1. All the poets who publish most in the paperback cluster in Type I.Types I and 2 poets have regularly produced essays and novels, most often published by major publishers. Type 2 includes poets also consecrated as novelists (Houellebecq, Pérec, Butor, and Sabatier). Type 4 poets 
Table 5. OMA paths and consecration

\begin{tabular}{|c|c|c|c|c|c|c|}
\hline & Type OMA I & Type OMA 2 & Type OMA 3 & Type OMA 4 & Mean & Standard dev. \\
\hline Grand prix (\%) & 20.83 & 4.76 & 5.26 & 10.00 & 8.39 & - \\
\hline Monography (\%) & 41.67 & 20.97 & 2.63 & 13.33 & 18.18 & - \\
\hline Theses (av.) & 6.92 & 4.98 & 0.52 & 2.40 & 3.69 & 9.79 \\
\hline Reviews (av.) & 52.38 & 60.55 & 5.26 & 18.56 & 37.10 & | | 3.08 \\
\hline Age at first publication with a major publisher & 37.96 & 39.15 & 39.95 & 40.50 & 39.10 & 11.56 \\
\hline Age at first paperback & 57.42 & 64.83 & 73.14 & 59.13 & 60.30 & 12.48 \\
\hline Age when first the subject of a thesis & 65.93 & 72.04 & 67.57 & 68.54 & 68.00 & 10.77 \\
\hline
\end{tabular}

spend more time with midrange publishers than Type 3 poets, who focus on minor publishers; Type 4 poets also have more access to major publishers and paperback publications. Our results confirm that similarly reputed poets tend to follow similar career paths. Poets' relations with publishers separate them into different social groups (Langley et al., 2019) of unequal reputation. An interesting result is that poets even when highly reputed continue working with small publishers, especially for poetry booklets or art books (with visual artists). Poetry careers are not linear, and this may explain why they are difficult to grasp. This is different from visual artists, whose professional networks change when their reputation grows (Giuffre, 1999), and from film professionals, whose reputation depends on their latest successes or failures (Bielby \& Bielby, 1999). In poetry, art books may represent an important source of income (Leclair, 2007), as art books are much more highly priced than standard editions. Furthermore, poets often publish their work in the format of small books, in which they can test new ideas or forms. Major publishers tend to take these on only later, once they can aggregate several small books into a larger edition that better suits their publishing expectations.

\section{Fixed patterns and other sources of reputation}

To further explore how these fixed patterns structure poets' careers, we compared our OMA types with the number of theses written (or currently being written) on poets' work, the number of reviews, whether or not they have been awarded the Grand Prix de Poésie and are included in the poetry monograph series, Poètes d'aujourd'hui. We also detail per cluster the average age of first publication at a major publisher, first publication in paperback and first thesis on their work. We present these results in Table 4.

Results clearly show that poets' fixed patterns correspond to different levels of reputation. They correspond not only to publishers and publishers' reputation but also to other main sources of reputation such as awards, reviews, and academic recognition. Furthermore, these patterns include time, as Type
I poets reach reviews and academic consecration earlier than others, with the relative exception of Type 4 poets. A closer look at our OMA clusters reveals that these fixed patterns correspond to different groups of poets, including publishing patterns, consecration but also genre and productivity. This career boundary separates poets into different social groups (Langley et al., 2019).

The Type I poet career corresponds to the 'ideal' career of the consecrated poet pictured earlier.Type I poets receive earlier and more academic and critical attention. Publishing trajectories coincide with one-time instances of consecration like academia, awards, and critical acclaim; in fact, all instances of consecration converge toward the same names. They publish with major publishers or in paperback at a 'young' age, which suggests that while the process is very long, most consecrated poets start to gain social recognition earlier than others do. This could be analyzed as another example of the Matthew effect (Merton, 1968) often observed in the arts (Menger, 2014). Jaccottet, Bonnefoy, and Roubaud are examples in kind, having accumulated all the signs of consecration, and published steadily with the best-reputed publishers (Gallimard and Le Seuil). Jaccottet is the only living poet to publish in the most prestigious French series, La Pléiade. Type I includes major theorists. Indeed, the ability to theorize poetic writing has been decisive since literary modernity (Friedrich, 1999). The focus on innovation and the preeminence of aesthetics over economics explain the importance of theory and poetics in poetry (Boschetti, 200 I). Poets have to situate themselves vis-à-vis other poets and existing aesthetics, and thus explain their aesthetic positions not only to peers but also to critics or even to publishers who have their own aesthetic identities. As Baudelaire, one of the founding fathers of French modern poetry, famously said, "the poet is the best critic." All major poets from the past (Hugo, Baudelaire, Mallarmé, Apollinaire, the Surrealists, etc.) and the present times (e.g., Bonnefoy, 1995; Jaccottet, 2015; Roubaud, 1978, 1995) wrote major theoretical and critical essays about poetry. This is not the case of novelists, who are not expected to produce such theoretical works, especially those situated on the commercial pole of the literary field (Bourdieu, 1996). 
Type 2 comprises somewhat less reputed poets. The cluster 'benefits' from the presence of 'novelists' who have received much attention, especially from critics (and academics, to a lesser extent), confirming that critics pay more attention to the novel than to poetry, which poets often bemoan. If we remove 'novelists,' the average numbers of theses and MLA mentions fall to 2.1 and 18.42, respectively. Others, like Ponge, though consecrated, have produced quite a meagre corpus, with longer periods of silence. Types 3 and 4 include less reputed poets, who spend less time in dominant publishing states, especially Type 3. Type 4 includes few poets having published regularly with major publishers (Réda, Noël), but mostly with minor ones. Their publishing trajectory is similar to that of less reputed poets in that they work mostly with midrange and minor publishers, but also have major publications, including paperbacks. They are consecrated poets, which explains that the average paperback age is close to Type I. Indeed, Type 4 includes few poets published in paperback - the aforementioned Réda and Noël - and the only two poets in paperback without having a steady relationship with major publishers. Also, in this cluster, we find the bestknown 'experimental poets' (Heidsieck, Blaine, and Chopin) who, though they have no major or paperback publications, still enjoy recognition within the world of poetry. Some, like Heidsieck, have been awarded the Grand Prix. This confirms the importance of conventions in reputation-making (Becker, 1984) as 'experimental' poetry breaks radically with the most widespread poetry conventions. Importantly, not all major publishers are equally important in shaping reputation: very few poets working with Flammarion have paperback publications, as Flammarion, unlike Gallimard, does not publish contemporary poetry in paperback. Though irregular, poetry careers are ordered and are composed of several steps. We see that these ordered steps do not happen for all poets in the same way, which flesh out more fully the idea of fixed patterns.

Academic consecration is especially important as the education system passes on the literary heritage to new generations and shapes the pantheon, particularly in France, where literature has played a key role in the making of the French State, the republican ideology, and its embodiment (Vaillant, 2017). The involvement of poets in the education system is thus important. Many prominent poets (Deguy, Bonnefoy, Roubaud, and Maulpoix) lead a two-sided 'academia/poetry' career, which is important, in that they can disseminate knowledge about poetry and encourage academic work on contemporary poetry (i.e., PhDs and symposia). However, very few creative writing programs exist in France. ${ }^{6}$ French poets

\footnotetext{
6. Creative writing programs started very recently in France, following the US model. There are currently eight academic creative writing programs in France (Bedecarré, 2017).
}

working in universities do not teach literary creation, but literary history, unlike in the United States (Spiro, 2004).

\section{The subjective dimension of poets' careers: Individual, shared, or collective awareness?}

If poets' careers follow fixed career patterns, to what extent are they aware of these career patterns? This was the second, subjective, dimension of our career boundary definition. In our case, the question is twofold. Are poetry actors aware that publishers shape poetry careers? Are they aware that silence, i.e., the rate of publication, structures poets' careers?

Our interviews and secondary data establish that poets are fully aware of the importance of publishers. Poets make this explicit in their accounts (e.g., Deguy, 1986; Maulpoix, 2001; Roubaud, 1995). For instance, Deguy (1988), one of the best reputed poets, criticized major publishers for not sufficiently considering poetry, insisting on the major publishers' power of literary consecration. Of our 20 interviewees, 18 mentioned the role of publishers and 16 evoked the hierarchy between these publishers. Poets insist more on reputation making, while booksellers insist more on distribution and reader recognition. This awareness impacts poets' career strategies. Poets know how important it is to strengthen their relationship with a big publisher, and that this eases later paperback publications. Jude Stéfan (2005) narrates how important his Gallimard editor, Georges Lambrichs, was in assembling around him and his Les Cahiers du Chemin series a group of poets (Stéfan, Deguy, Réda, Macé, Perros, and Janvier, all now published in the Gallimard paperback series). This is why prominent poets have established long-term relations with reputed publishers, as our data reveals. Examples include Ray, Jaccottet, and Bonnefoy with Gallimard; Roubaud, Pleynet, and Roche with Le Seuil; Deluy, Di Manno, and Rossi with Flammarion; and Fourcade, Hocquard, and Boyer with POL. Jaccottet's letter to Gaston Gallimard demonstrates to what extent he is, like our interviewee, aware of Gallimard's standing in poetry, and more specifically, its paperback series. This letter demonstrates his esteem of publishing in the series, resulting from his long-standing relationship with Gallimard:

Nothing could please me more than publishing a selection of poems in the series. I have already made a first choice, covering the three books published by Gallimard, and ending with Leçons. It would be a volume of poetry 1946-1966.

Editors also emphasize the role of publishers in poets' careers. The editor of the most-read poetry website pays homage to poet Marie-Claire Bancquart, who died recently, insisting

\footnotetext{
Philippe Jaccottet, "Letter to Gallimard," November 28, 1968. The book would be published in 1971.
} 
again on the consecration of a publication in Poésie/Gallimard, the Gallimard poetry paperback series:

Poezibao learned last night with deep sadness the death of MarieClaire Bancquart. She leaves behind considerable poetic and critical work, to which Poezibao will return soon. She had just received, at last, the much-awaited consecration of a publication in Poésie/ Gallimard. $^{8}$

The editor of POL (Paul Otchakovski-Laurens, who died recently) explained how important it was to follow a poet over his career (see Centre international de poésie Marseille, 1992) as only time can be a source of reputation and money, as much for publishers as for poets. Gallimard has historically bet on the long term (Assouline, 2006). It is also a way to reduce risk, as a publisher needs to sell more in paperback than in hardback to be profitable. One editor of a paperback poetry series stresses that a certain number of hardback publications and critical acclaim are required before moving on to paperbacks: "in fact, for a poet to be published here [in paperback], he or she would have to have published at least one book with a print run of 2000 copies [in hardback, with a major publisher]" (interview, February 8, 2005). Poets are aware of this 'rule.' A poet emphasizes the impact of Gallimard's paperback series and decries its overly classical bent. His comment insists on publishers' aesthetic identity, which we will come back to later:

That said, there could be a bias. Gallimard's Poésie collection is indeed omnipresent - it's the major distribution channel for poetry in France - and it has an idea, which l'd say is blinkered, of what is contemporary. They only see one school, one trend. Especially when you consider that they don't publish three winners of the Grand Prix National de Poésie [the most prestigious poetry prize in France]. It's almost unfair, as regards ... except for Bernard Heidsieck, these poets are hardly revolutionary ... Fourcade really follows in the wake of Char, and Tortel is frankly no great innovator either (interview, September 20, 2004).

Those mentioned here as new or potential poets for the Gallimard paperback series, however, are already established with major publishers, with the exception of Heidsieck.

Poets are not the only actors to be so alert to publishers. It is also the case of both critics and booksellers. When Jaccottet published in La Pléiade in 2014, the event triggered the publication of 65 articles in 2 months, all insisting on Jaccottet's consecration. It was extraordinary attention for a poet in the French general press. Similarly, booksellers are aware of the importance of publishers. They, too, use publishers to understand the shifting sands of contemporary poetry. Publishers' reputations directly affect sales, and it is easier for booksellers to work with major publishers that readers know better. As this Parisian bookseller indicates:

\footnotetext{
8. https://poezibao.typepad.com/poezibao/2019/02/disparition-marie-claire-bancquarthtml.
}

I would love there to be a diverse poetry section in every bookstore, and not just a Gallimard paperback poetry stand, hidden away in some corner, with their collection in alphabetical order ... It's easy to work with Gallimard, with other publishers it's not so much the case, and l'd like it to be that simple with all publishers.

The role of publishers in the poetry field is all the more structuring since the hierarchy of publishers is highly stable, major publishers having remained the same since at least World War II, like many midrange publishers (Bourdieu, 1999).

Another reason why poetry actors use publishers to evaluate poets is that publishing here or there is also an aesthetic signal. Gallimard publishes more classic 'lyrical' poetry. The poet cited earlier decried not only the power of Gallimard in the poetry economy but also its 'blinkered idea' of poetry. Gallimard subsidiary POL seeks more 'experimental' work (Guillaume, 2003). Le Seuil has published avant-garde poets (Pleynet, Roche, and Faye), and Flammarion publishes more formalist poets, as its editor claims (Di Manno, 1998). A distinguishing aesthetic is true for smaller publishers also: Arfuyen specializes in spiritual poetry, Champ Vallon in lyrical poetry, while Al Dante publishes 'experimental' poetry, such as sound poetry. This distinctive signaling enables poetry actors to situate poets' trajectories not only in terms of reputation but also in terms of aesthetics. In addition, editors are also very often poets, who express themselves publicly in books and in the press, making clear their aesthetic orientation, which other poetry actors can easily observe through publishers' lists. Poets have a deep knowledge of their field and its history. This knowledge includes the weight and the specific orientations of publishers.

The question remains whether this awareness of the impact of publishers on poetry careers is shared or collective. The publisher's role in defining poets' trajectories is not institutionalized, as collective awareness would require. No rule or collective entity (regulation, professional association, and trade union) and no institutionalized professional ethics organize poetry careers, as Sapiro (2019) notes. Whilst publishers apply certain criteria to the order of publication (hardback before paperback, for example), these rules are neither systematic nor institutionalized. The choice remains that of the publishers. Association with publishers is a shared boundary, combining fixed patterns and shared awareness.

The fact that poets remain silent for several years or, on the contrary, are prolific is not a decisive feature in assessing their activity. Our interviewees never mention the pace of publication, nor its potential impact on careers and reputation. Only 2 of the 65 articles written after Jaccottet's publication in La Pléiade mention that Jaccottet is a prolific author, and none point out that at the beginning of his career, he remained silent for 10 years. Poetry actors are rarely aware that silence shapes poetry careers. On the other hand, some poets were mindful of this fact, like Ponge, who thought that his late recognition 
was partly due to his slow pace of publication, and that he had to publish more regularly (Doga, 2016). Silence is an unknown boundary, with fixed patterns but individual awareness.

\section{Discussion}

We found only two types of boundaries from our typology in the case of French poets. Throughout history, modern societies have witnessed an increasing division of labor (Weber, 1978). Social worlds are now organized around specific characteristics that shape careers (Becker, 1984). It would thus have been very surprising to find all the boundary types our concept offers within the same social world. For instance, we would not find any organization-based boundary in poets' careers. Similarly, they neither rest on any specific training nor institutional credentials unlike lawyers or physicians; no professional organization has endeavored to organize poets' careers. This makes it impossible to find an institutionalized boundary in the case of poets. The case of poets suggests that we are unlikely to find all boundary types in a single case. Our typology rather helps to grasp very different cases as we will discuss in the next sections, using our findings as well as examples from the literature to illustrate its capacity to approach a wide range of different forms of careers in different contexts. We discuss first the two boundary types we found in the case of poets, before briefly discussing the three other types with examples. We recall that one of our boundary types, labeled incoherent (no fixed patterns and collective awareness), does not exist in the social world.

\section{Shared boundaries}

Shared boundaries combine fixed patterns with shared awareness. Publishers, and their reputation, represent a shared boundary in the case of poets. Why is this so? What matters in poetry is reputation, which can yield profits much later. If we exclude poetry magazines, which remain confidential, publishers are the first to select poets, and in doing so, send the first strong reputation signal to other poetry actors, including readers. Paperback publication is important because, in addition to a strong signal of quality, it makes a poet's work easily accessible, especially for students. This encourages academics and teachers to include poets published in paperback in their curricula (Maulpoix, 200 I), and we have seen the extent to which academic consecration is decisive in poets' careers. Critics, also, pay much attention at which publisher a book is published (Boschetti, 200I; Cerisier, 2009). The reputation of publishers therefore counts for a great deal, all the more, so because the hierarchy of publishers is not likely to change with the dominance of 'old' and established literary publishers (Bourdieu, 1999). However, this is not set in stone. Before the 19th century, publishers had little impact on poets' careers as they were initially local booksellers publishing books on a small scale (Viala, 1985).
Many types of careers follow fixed patterns, even though these patterns are not institutionalized, from modern artists (Braden, 2009; Wijnberg \& Gemser, 2000) to engineers and ICT workers (Ituma \& Simpson, 2009). When these fixed patterns are easily observable, actors become aware of them through professional socialization. This is the case of organizational careers, when people are aware of the rules that govern promotion in their organization (Wilensky, 1961). Such careers have not disappeared (Bagdadli \& Gianecchini, 20।8; LipsWiersma \& Hall, 2007), as in accounting firms (Lupu, 20I2) and multinationals (Zhao \& Zhou, 20l3).

\section{Unknown boundary}

Unknown boundaries combine fixed patterns and individual awareness. In the case of poets, silence is an unknown boundary, and this may be surprising. The most renowned poets (Bonnefoy, Jaccottet, and Roubaud) have been prolific. However, poets' lack of awareness of the role of silence in poetry careers can be explained by the fact that they gain their reputation only over the very long term, unlike in commercial literary creation, where artworks can provide immediate success, like for Zadie Smith (Pouly, 2016). The case of poets is different. A poet is consecrated for his whole career over the long term rather than for a single book (Boschetti, 200 I). In this regard, the case of poets is also different from that of visual artists, whose work has a value as a unique artefact (Moulin, 1994). Another reason explaining why poets are not aware of the role of silence is that books do not provide poets with much money. There is much less incentive to publish regularly, unlike novelists living by their pen. Publishing more or fewer books only loosely impacts the material life of poets, who often have less time for artistic creation because of their second jobs.

Unknown boundaries may be common when individuals ignore which rules govern their social worlds, as critical sociology or management research has emphasized (Alvesson, Bridgman, \& Willmott, 2009; Bourdieu, 1995). For instance, we can understand gender as an unknown boundary (Bamberger, AdmatiDvir, \& Harel, 1995; Biemann et al., 20 I2). In this case, they have long been unknown (and maybe still are) because they are illegitimate. This is the case for the 'mommy track' in legal professions (Hagan et al., 1991) : gender shapes women's careers in these fields much more than official rules, but actors are unaware of it. Another example is that of French company directors. François and Lemercier (2014a, 20।4b) have shown that directors in the biggest French firms share the same very narrow background, showing that these careers are strongly socially boundaried. They studied managers sitting on two or more boards of directors in the 120 biggest companies on the Paris stock exchange. Seventy-nine percent come from the upper classes (entrepreneurs, liberal professions, top managers, etc.). In 2009, less than 10\% had not graduated from a Grande 
Ecole (the best reputed French higher education institutions), and $66 \%$ had graduated from the Ecole Polytechnique, Sciences-Po, and/or the Ecole Nationale d'Administration, which together award less than 500 degrees a year. This last figure contrasts with the total number of French students, 2.3 million, and emphasizes the weight of social capital in shaping careers (Bourdieu, 1980). However, the fact that the path to top management positions in larger French firms is so narrow and remains largely unknown, even among French executives (François \& Lemercier, 20|4a).

\section{Other boundary types}

In the last part of this section, we briefly discuss the three remaining cases of our typology: the institutionalized boundary, the symbolic boundary, and the proto-boundary. Institutionalized boundaries combine fixed patterns and collective awareness. This is the case of professions organized according to institutionalized rules, such as academia or the legal and medical professions; there are fixed patterns (tenure, choice of specialization after an examination) which individuals cannot ignore. Quite often, this institutionalization involves professionals themselves, as in the case of academics (Bedeian et al., 2010), pharmacists (Rodrigues et al., 2016) and lawyers (Karpik, 1995). It was also the case in the arts when artists' careers were regimented by the French Académie (Heinich, 1983), suggesting once again that career boundaries may radically change. Such boundaries structure intellectual professions and expert labor especially (Abbott, 1988).

Proto-boundaries occur when some actors (but not all) believe that certain fixed patterns - based on a specific boundary - structure careers, despite the fact that this boundary does not organize careers. We draw the concept from Abbott (1995b). This happens because actors have no access to the relevant information, or even because profound changes make many of them unaware of the boundaries structuring their professional world. The end of the permanent employment system in Japan provides a good example (Ahmadjian \& Robinson, 200 I). In the case of artistic careers, many amateur writers think that launching a career means publishing a book even through self-publishing (Mouaci, 200I), whereas we have shown that poetry careers depend on which publisher a poet works with. Self-publication is a dead end, as these publishers do not provide amateurs with reputation: it is a handicap rather than an asset. To know this, one has to be part of the poetry world. Another case is that of lawyers. For many years, lawyers' careers were structured in two main steps: lawyers first worked for a legal practice ${ }^{9}$ before becoming partners or

\footnotetext{
9. In France, lawyers start their career working under the specific status of 'collaborateur,' being hired by a practice as an independent worker, having, in theory at least, and in addition to their work in the practice, the opportunity to develop their own clientele.
}

founding their own practice with colleagues (Karpik, 1995). Some lawyers still follow this career model, whereas increasingly lawyers spend their whole careers working for different practices, either freelance or as employees. The market and the organization of the profession are changing (Bessy, 2010), with larger practices reluctant to offer partnerships to newcomers and preferring to hire well-paid, highly specialized lawyers (Haeri, 20 I7). In other words, the boundary is not where some actors think it is (the status of employee or partner and the income pertaining to that status), but rather between different modes of professional organization, which largely overlap the geographical boundary between Paris, the provinces, and the legal domains (business law or family law, for instance). This false perception remains individual: not all lawyers share this view, which will depend on their own professional trajectory and their knowledge of the profession.

Symbolic boundaries are close to proto-boundaries, but the false perception actors have not individual but shared. It may happen when boundaries contradict common views, or when individuals have few possibilities to get information about their social world. For instance, Bourdieu and Passeron (1964) famously argued that the correlation between social class, academic success, and professional achievement is ignored though it shapes careers, because it contradicts the meritocracy ideology and the supposed social role of the education system. It can also occur when a professional identity is particularly strong, career structure being considered a key feature of this identity. Architects face a similar situation to lawyers. They also see their career as a progression from employee to entrepreneur, whereas the job market is changing. But as Chadoin (2007) has shown, they have less knowledge of their social world, probably because architecture is not as formally organized as the legal profession, and unlike for architects, bar associations produce a lot of information and are also responsible for training.

\section{Conclusion}

The contributions of this article are twofold. First, we offer a concept of career boundary based on fixed patterns and actor awareness, which fully integrates the objective and subjective dimensions of careers. It leads to a five-case typology of career boundaries, which enables us to search for boundaries in various social settings, theoretically and empirically. Second, we tested this framework on the case of artistic careers and found that they are boundaried by reputation. Poets' relations with publishers, which are instances of consecration, structure their careers and chances of success. Similarly, reputed poets tend to follow similar career patterns. We thus investigate another type of non-organizational career boundary, namely, reputation. As Becker (1984) notes, careers sum up the organization of a social world, and the impact of reputation on artistic careers mirrors that of social recognition on artistic fields. It may 
extend beyond the case of artistic careers as reputation is one of the main assets of workers in many other fields (Bar-lsaac \& Deb, 20।4; Blickle, Schütte, \& Wihler, 20l8), including among others professions in the Anglo-Saxon sense, such as law, medicine, and psychology (Abbott, 1988), consultancy (Lupu, 20 I2), and academia (Bedeian \& Feild, 1980). We found two out of our five types of career boundaries, which are not surprising given the diversity and complexity of modern societies: other types of career boundaries may be identified in other social contexts. This article thus contributes both to the literature on careers and on creative industries.

Our work questions the boundaryless argument (see Budtz-|ørgensen et al., 2019; Rodrigues \& Guest, 2014b) on a new basis: we tend to conclude that careers are boundaryless because we have not searched for boundaries where there are. For instance, we may have searched in a given setting for organizational career boundaries and found none. But this does not mean that there are no other boundaries shaping careers in this specific setting. The case of artists here is illuminating. Their careers are boundaried by the most salient characteristic of creative fields, reputation (Becker, 1984; Lang \& Lang, 1988), but not by the intra- or interorganizational boundaries, which are the most visible.

To conclude, we suggest that the most common career boundary types are likely to be the institutionalized, shared, and unknown ones. Institutionalized boundaries concern first 'the professions,' as American sociology has defined them, further suggesting that, increasingly, social activities are professionally organized (Abbott, 1988). Of course, institutionalized rules hardly regulate all occupations. If fixed patterns structure careers though they are not subjected to institutionalized rules, the question is whether actors are aware of these patterns or not. We might suppose that quite often they are, because of professional socialization, which contributes to career success (Anderson-Gough, 20 I8; Grima \& Glaymann, 20 I2). However, this is not always true. Actors may well not be aware - or may be only partially aware - of the rules of their social world, as critical sociology and critical management have long insisted (Bourdieu, 1978; Clegg, 1981; Foucault, 2004), suggesting that unknown boundaries may also be quite common. This may happen, especially, when social domination processes impact career development, such as race or gender (Castilla, 2008). These suggestions open directions for future research to explore which kinds of boundaries shape careers in other social settings. We have provided the theoretical and methodological apparatus to lead such exploration.

\section{Acknowledgments}

The authors would like to thank the Associate Editor Thomas Roulet and the anonymous reviewers for their insightful suggestions and comments, which greatly contributed to improve this manuscript.

\section{References}

Aasve, A., Betti, G., Mazzuco, S. \& Mencarini, L. (2007). Marital disruption and economic well being: A comparative analysis. Journal of Royal Statistical Society, I 70(3), 78 I-799. doi: I 0.1 I I |/j. I467-985X.2007. 00483.x

Abbott, A. (1988). The system of the professions. An essay of the division of expert labour. Chicago University Press.

Abbott, A. (1995a). Boundaries of social work or social work of boundaries?: The social service review lecture. The Social Service Review, 69(4), 545-562. doi: | $0.1086 / 604 \mid 48$.

Abbott, A. (1995b). Things of boundaries. Social Research, 62(4), 857-882. www.jstor.org/stable/4097| | 27.

Abbott, A. \& Hrycak, A. (1990). Measuring resemblance in sequence data: An optimal matching analysis of musicians' careers. American Journal of Sociology, 96(I), | 44-185. doi: 10.1086/229495

Abbott, A. \& Tsay, A. (2000). Sequence analysis and optimal matching methods in sociology: Review and respect. Sociological Methods \& Research, 29( I), 3-33. doi: 10.1 177/0049 |2410002900 I00 I.

Ahmadjian, C. L. \& Robinson, P. (200 I). Safety in numbers: Downsizing and the deinstitutionalization of permanent employment in Japan. Administrative Science Quarterly, 46(4), 622-654. doi: I0.2307/3094826

Alvesson, M., Bridgman, T. \& Willmott, H. (2009). The Oxford handbook of critical management studies. Oxford University Press.

Anderson-Gough, F. (20 I 8). Making up accountants: The organizational and professional socialization of trainee chartered accountants. Routledge.

Arthur, M. B. (1994). The boundaryless career: A new perspective for organizational inquiry. Journal of Organizational Behavior, 15(4), 295-306. doi: 10.1002/job.4030I50402

Arthur, M. B. (2014). The boundaryless career at 20: Where do we stand, and where can we go? Career Development International, 19(6), 627-640. doi: | 0. I 108/CDI-05-20 I4-0068.

Ashforth, B., Kreiner, G. \& Fugate, M. (2000). All in a day's work: Boundaries and micro role transitions. Academy of Management Review, 25(3), 472-491. doi: I0.5465/amr.2000.33633I5.

Assouline, P. (2006). Gaston Gallimard, un demi-sècle d'édition française. Gallimard.

Bagdadli, S. \& Gianecchini, M. (20 | 8). Organizational career management practices and objective career success: A systematic review and framework. Human Resource Management Review, 29(3), 353-370. doi: 10.1016/j.hrmr.2018.08.001.

Bamberger, P., Admati-Dvir, M. \& Harel, G. (1995). Gender-based wage and promotion discrimination in Israeli high-technology firms: Do unions make a difference? The Academy of Management journal, 38(6), |744-1761. doi: 10.5465/256853

Bar-Isaac, H. \& Deb, J. (20 I 4). What is a good reputation? Career concerns with heterogeneous audiences. International Journal of Industrial Organization, 34, 44-50. do: $10.1016 /$ j.jijindorg.2014.02.012

Barley, S. R. (1989). Careers, identities, and institutions: The legacy of the Chicago School of Sociology. In M. B. Arthur, D. T. Hall, \& B. S. Lawrence (Eds.), Handbook of career theory (pp. 4I-65). Cambridge University Press.

Barley, S. R. \& Tolbert, P. S. (1997). Institutionalization and structuration: Studying the links between action and institution. Organization Studies, I8(I), 93-93. doi: I0. I 177/0 I708406970। 800106

Becker, H. (1984). Art worlds. University of California Press.

Becker, H. S. (1952). The career of the Chicago Public School teacher. The American Journal of Sociology, 57(5), 470-477. doi: 10. I086/22 I 015

Becker, H. S. (1963). Outsiders: Studies in the sociology of deviance. Free Press. Becker, H. S. \& Carper, J. (1956). The elements of identification with an occupation. American Sociological Review, 2 I (3), 34 I-348. 
Bedecarré, M. (2017). Apprendre à écrire? Des formations étasuniennes de creative writing aux masters de création littéraire en France. In G. Sapiro \& C. Rabot (Eds.), Profession? Écrivain. CNRS.

Bedeian, A. G., Cavazos, D. E., Hunt, J. G. \& Jauch, L. R. (20 I 0). Doctoral degree prestige and the academic marketplace: A study of career mobility within the management discipline. Academy of Management Learning \& Education, 9( I), I I-25. doi: I0.5465/amle.9. I zqr I I

Bedeian, A. G. \& Feild, H. S. (1980). Academic stratification in graduate management programs: Departmental prestige and faculty hiring patterns. Journal of Management, 6(2), 99-1 I5. doi: I0.1 I77/0।492063 8000600201

Bernard, M.-J. \& Barbosa, S. D. (20 I 6). Résilience et entrepreneuriat: Une approche dynamique et biographique de l'acte d'entreprendre.M@n@ gement, 19(2), 89-123. doi: 10.3917/mana.192.0089.

Bessy, C. (20 I0). Les avocats, un marché professionnel déstabilisé. Formation emploi. Revue Française de Sciences Sociales, 1 / 0, 35-48. http://journals. openedition.org/formationemploi/3026

Bielby, W. T. \& Bielby, D. D. (1999). Organizational mediation of project-based labor markets:Talent agencies and the careers of screenwriters. American Sociological Review, 64(I ), 64-85. doi: I0.2307/2657278

Biemann, T., Zacher, H. \& Feldman, D. C. (20I2). Career patterns: A twenty-year panel study. Journal of Vocational Behavior, 8I(2), I59-170. doi: $10.1016 /$ j.jvb.20 I2.06.003

Bird, A. (1994). Careers as repositories of knowledge: A new perspective on boundaryless careers. Journal of Organizational Behavior, 15(4), 325-344. doi: I0. I 002/job.4030 I50404

Bird, A., Gunz, H. P. \& Arthur, M. B. (2002). Careers in a complex world:The search for new perspectives from the "new science". M@n@gement, 5(I), I-| 4, doi: I0.39|7/mana.05 I.000 I

Bitektine, A. (20I I). Toward a theory of social judgments of organizations: The case of legitimacy, reputation and status. Academy of Management Review, 36( I), I5 I-179. doi: I0.5465/amr.2009.0382.

Blickle, G., Schütte, N. \& Wihler, A. (20।8). Political will, work values, and objective career success: A novel approach - The trait-reputationidentity model. Journal of Vocational Behavior, 107, 42-56. doi: 10.1016/j. jvb.2018.03.002

Bol,T. (20 I5). Has education become more positional? Educational expansion and labour market outcomes, 1985-2007. Acta Sociologica, 58(2), |05-|20. doi: | 0. I 177/000 | 6993|55709|8

Bonnefoy,Y. (1995). La vérité de parole. Gallimard.

Bóo, F. L., Rossi, M. A. \& Urzúa, S. S. (2013). The labor market return to an attractive face: Evidence from a field experiment. Economics Letters, I/8(1), 170-172. doi: 10.1016/j.econlet.2012.10.016

Boschetti, A. (200I). La poésie partout: Apollinaire, homme-époque (1898-19/8). Seuil.

Bourdieu, P. (1978). Classement, déclassement, reclassement. Actes de la Recherche en Sciences Sociales, 24(I), 2-22. doi: I0.3406/arss. I978.26I3

Bourdieu, P. (1980). Le capital social. Notes provisoires. Actes de la Recherche en Sciences Sociales, 31, 2-3.

Bourdieu, P. (1995). Outline of a theory of practice. Cambridge University Press.

Bourdieu, P. (1996). The rules of art: Genesis and structure of the literary field. Stanford University Press.

Bourdieu, P. (1999). Une révolution conservatrice dans l'édition. Actes de la Recherche en Sciences Sociales, 126(1), 3-28. doi: 10.3406/ arss. 1999.3278.

Bourdieu, P. \& Passeron, J.-C. (1964). Les héritiers: les étudiants et la culture. Editions de Minuit.

Bowness, A. (1989). The conditions of success. How the modern artists rise to fame. Thales \& Hudson.
Braden, L. E. (2009). From the armory to academia: Careers and reputations of early modern artists in the United States. Poetics, 37(5-6), 439-455. doi: I0. I 10 6/j.poetic.2009.09.004

Budtz-Jørgensen, J., Johnsen, C. G. \& Sørensen, B. M. (20।9). Against boundarylessness: The liminal career of the flexible employee. Organization, 26(6), 917-935. doi: 1 0.1 177//3505084 | 8821005

Castilla, E. J. (2008). Gender, race, and meritocracy in organizational careers. American Journal of Sociology, I I 3(6), | 479-1526. doi: 10. I086/588738

Caves, R. E. (2000). Creative industries: Contracts between art and commerce. Harvard University Press.

Centre international de poésie Marseille. (1992). Les états-généraux de la poésie. Musées de Marseille Editions.

Cerisier, A. (2009). Une histoire de la NRF. Gallimard.

Chadoin, O. (2007). Etre architecte: les vertus de l'indétermination. Presses Universitaires de Limoges.

Childress, C., Rawlings, C. M. \& Moeran, B. (2017). Publishers, authors, and texts: The process of cultural consecration in prize evaluation. Poetics, 60, 48-61. doi: 10.1016/j.poetic.2016.10.001

Clarke, M. (2013). The organizational career: Not dead but in need of redefinition. The International Journal of Human Resource Management, 24(4), 684-703. doi: I0. I080/09585 I 92.20 I 2.697475

Clegg, S. (1981). Organization and control. Administrative Science Quarterly, 26(4), 545-562. doi: 10.2307/2392339

Cnossen, B., Dekker, E. \& Taskin, L. (2017). Management and organization in the work of Michel Houellebecq. M@n@gement, 20(3), 300-320. doi: | 0.39|7/mana.203.0300

Collot, M. (2000). Introduction à la poésie française du XXe siècle. In M. Collot (Ed.), Anthologie de la poésie française du XXème siècle, Tome II (pp. 835-860). Gallimard.

Collot, M. (2019). Le chant du monde dans la poésie française contemporaine. Corti.

Court, S. (1998). Academic tenure and employment in the UK. Sociological Perspectives, 4 I (4), 767-774. doi: I0.2307// 389668

Craig, A. (2007a). Practicing poetry. A career without a job. In C. Calhoun (Ed.), Practicing cultures (pp. 35-56). Routledge.

Craig, A. (2007b). Sustainability, reciprocity, and the shared good(s) of poetry. The Journal of Arts Management, Law, and Society, 37(3), 257-270. doi: I0.3200/JAML.37.3.257-270

Craig, A. \& Dubois, S. (20I0). Between art and money:The role of readings in contemporary poetry, a new economy for literature? Poetics, 38(5), 44 I-460. http://doi.org/ | 0. I 0 | 6/j.poetic.20 I 0.07 .003

Dafou, E. (2018). Career boundaries and boundary-crossing by public sector employees. Career Development International, 23(2), 197-211. doi: | 0.1 | 08/CDI- |2-2016-024|

Dany, F., Louvel, S. \& Valette, A. (20I I). Academic careers: The limits of the 'boundaryless approach' and the power of promotion scripts. Human Relations, 64(7), 97|-996. doi: I 0.1 1 77/00 I87267। 0393537

Deguy, M. (1986). Choses de la poésie et affaires culturelles. Hachette.

Deguy, M. (1988). Le comité. Champ Vallon.

Delacour, H. \& Leca, B. (20II). The decline and fall of the Paris Salon: A study of the deinstitutionalization process of a field configuring event in the cultural activities. M@n@gement, 14(I),436-466, doi: 10.3917/ mana. 141.0436

Di Manno,Y. (1998). La poésie contemporaine en questions. Entretien avec Lionel Destremeau. Prétexte, 9.

Doga, M. (2016). Francis Ponge: trajectoire d'une reconnaissance littéraire tardive. COnTEXTES. Revue de Sociologie de la Littérature, I 7. doi: I0.4000/ contextes.6191.

Donnelly, R. (2008). Careers and temporal flexibility in the new economy: An Anglo-Dutch comparison of the organisation of consultancy work. 
Human Resource Management Journal, I8(3), 197-2 I5. doi: I0.1 I I I/ j. $1748-8583.2008 .00072 . x$

Dowd, T. J. \& Pinheiro, D. L. (20/3). The ties among the notes: The social capital of jazz musicians in three metro areas. Work and Occupations, 40(4), 43 I-464. doi: I 0.1 I 77/07308884I 3504099

Dries, N., Van Acker, F. \& Verbruggen, M. (20।2). How 'boundaryless' are the careers of high potentials, key experts and average performers? Journal of Vocational Behavior, 8 I (2), 27I-279. doi: I0.10 I 6/j.jvb.20 I I. 10.006

Duberley, J., Cohen, L. \& Mallon, M. (2006). Constructing scientific careers: Change, continuity and context. Organization Studies, 27(8), | I 3 |- | | 5 | doi: 10.1 177/0170840606064105

Dubois, S. (20I I). Joining the literary pantheon: How contemporary French poets attain renown. Revue Française de Sociologie, 52(5), 87-1I5. 10.3917/rfs.525.0087.

Durand, P. (2005). L'art d'être Hugo: lecture d'une poésie siècle. Actes Sud.

Durand, P. \& Glinoer, A. (2008). Naissance de l'éditeur: l'édition à l'âge romantique. Les Impressions nouvelles.

Essers, C. \& Benschop, Y. (2007). Enterprising identities: Female entrepreneurs of Moroccan or Turkish origin in the Netherlands. Organization Studies, 28(I), 49-69. doi: I0.1 I 77/0170840606068256

Essig, E. \& Soparnot, R. (2019). Re-thinking gender inequality in the workplace - A framework from the male perspective.M@n@gement, 22(3). 373-4 I0. doi: I0.39 I7/mana.223.0373.

Forest, P. (1995). Histoire de Tel Quel. Seuil.

Foucault, M. (2004). Naissance de la biopolitique. Gallimard/Seuil.

François, P. \& Lemercier, C. (20|4a). Ebbs and flows of French capitalism. In T. David \& G. Westerhuis (Eds.), The power of corporate networks (pp. 149-168). Routledge.

François, P. \& Lemercier, C. (20।4b). State or status capitalism? Some insights on French Idiosyncrasies using an interlocking directorates approach. Economic Sociology, 15(2), 17-33. https://www.econstor.eu/ handle//04/9/I56029

Franssen, T. (2015). Diversity in the large-scale pole of literary production: An analysis of publishers' lists and the Dutch literary space, 2000-2009. Cultural Sociology, 9(3), 382-340. doi: I 0. I I 77/ I 7499755 । 5583729

Franssen, T. \& Kuipers, G. (20।3). Coping with uncertainty, abundance and strife: Decision-making processes of Dutch acquisition editors in the global market for translations. Poetics, 4I(I), 48-74. doi: 10.1016/j. poetic.2012.1 I.001

Franssen, T. \& Kuipers, G. (20I5). Sociology of literature and publishing in the early 21 st century: Away from the centre. Cultural Sociology, 9(3), 29|-295. doi: | 0.1 I77// 74999755 |5594467

Friedrich, H. (1999). Structure de la poésie moderne. Librairie Générale Française.

Giuffre, K. (1999). Sandpiles of opportunity: Success in the art world. Social Forces, 77(3), 8I5-883. doi: 10.1093/sf/77.3.8I5

Gleize, J.-M. (2003). Parnasses contemporains. De quelques revues. In D. Guillaume (Ed.), Poétiques et poésies contemporaines (pp. 69-83). Le temps qu'il fait.

Granovetter, M. S. (1973). The strength of weak ties. American Journal of Sociology, 78(6), 1360-1380. doi: 10.1086/225469

Grima, F. \& Glaymann, D. (20 I2). A revisited analysis of the exit-voice-loyaltyneglect model: Contributions of a longitudinal and conceptually extended approach.M@n@gement, 15(I), I-41. doi: 10.3917/mana. 5 I.0002

Gubler, M., John, A. \& Crispin, C. (2014). Organizational boundaries and beyond: A new look at the components of a boundaryless career orientation. Career Development International, 19(6), 64 I-667. doi: I0.1 I08/ CDI-I I-20|3-0|43
Guillaume, D. (2003). Poétiques et Poésies contemporaines. Le temps qu'il fait.

Gunz, H., Peiperl, M. \& Tzabbar, D. (2007). Boundaries in the study of career. In H. Gunz \& M. Peiperl (Eds.), Handbook of career studies (pp. 47I-494). Sage.

Gunz, H. P., Lichtenstein, B. M. B. \& Long, R. G. (2002). Self-organization in career systems: A view from complexity science. $M @ n @ g e m e n t, ~ 5(I)$, 63-88. doi: $10.3917 /$ mana.05।.0063

Haar, J. M., Russo, M., Suñe, A. \& Ollier-Malaterre, A. (2014). Outcomes of work-life balance on job satisfaction, life satisfaction and mental health: $A$ study across seven cultures. Journal of Vocational Behavior, 85(3), 36 I-373. doi: $10.1016 /$ j.jvb.20 14.08 .010

Haeri, K. (2017). L'avenir de la profession d'avocats. Ministère de la Justice.

Hagan, J., Zatz, M., Arnold, B. \& Kay, F. (|99|). Cultural capital, gender, and the structural transformation of legal practice. Law \& Society Review, 25(2), 239-262. doi: 10.2307/3053798

Heinich, N. (1983). La perspective académique. Peinture et tradition lettrée: la référence aux mathématiques dans les théories de l'art au XVllème siècle. Actes de la Recherche en Sciences Sociales, 49, 47-70. doi: 10.3406/arss. 1983.2198

Heinich, N. (2005). L'élite artiste: excellence et singularité en régime démocratique. Gallimard.

Henz, U. \& Mills, C. (20I5). Work-life conflict in Britain: Job demands and resources. European Sociological Review, 3I(I), I-13. doi: I0.1093/esrl jcu076

Hernes, T. (2004). Studying composite boundaries: A framework of analysis. Human Relations, 57(1), 9-29. doi: 10.1 177/00 I87267040427 I2.

Hewer, P., Brownlie, D. \& Kerrigan, F. (2013). 'The exploding plastic inevitable': 'Branding being', brand Warhol \& the factory years. Scandinavian Journal of Management, 29(2), 184-193. doi: 10.1016/j. scaman.20I3.03.004

Hirsch, P. M. (1972). Processing fads and fashions: An organization-set analysis of cultural industry systems. American Journal of Sociology, 77(4), 639-659. doi: 10.1086/225192

Hoock, H. (2003). The King's artists: The royal academy of arts and the politics of British culture 1760-1840. Oxford University Press.

Hughes, E. C. (1937). Institutional office and the person. American Journal of Sociology, 43(3), 404-413. doi: I0.1086/2 I77| I

Hughes, E. C. (1996). Carrières, cycles de vie et tournant de l'existence. In E. C. Hughes (Ed.), Le regard sociologique (pp. 165-174). Editions de l'EHESS.

Inkson, K., Gunz, H., Ganesh, S. \& Roper, J. (20I2). Boundaryless careers: Bringing back boundaries. Organization Studies, 33(3), 323-340. http:// doi.org/ | 0.1 I 177/0 | 708406 | | 435600

Ituma, A. \& Simpson, R. (2009). The 'boundaryless' career and career boundaries: Applying an institutionalist perspective to ICT workers in the context of Nigeria. Human Relations, 62(5), 727-761. doi: I0. I 77 I 0018726709103456

Jaccottet, P. (20I5). Une transaction secrète. Gallimard.

Jones, C. (1996). Careers in project networks: The case of the film industry. In M. B. Arthur \& D. M. Rousseau (Eds.), The boundaryless career: A new employment principle for a new organizational era (pp. 58-75). Oxford University Press.

Jones, C. (200 I). Co-evolution of entrepreneurial careers, institutional rules and competitive dynamics in American film, 1895-1920. Organization Studies, 22(6), 9 | I-944, doi: 10.1 177//0 I 7084060 I 226002

Karpik, L. (1995). Les avocats. Entre l'Etat, le public et le marché. XIllème XXème siècle. Gallimard.

Kilduff, M. \& Corley, K. G. (1999).The diaspora effect:The influence of exiles on their cultures of origin. M@n@gement, 2(I), I-12. https://management-aims.com/index.php/mgmt/article/view/4|40 
King, Z., Burke, S. \& Pemberton, J. (2005). The 'bounded' career: An empirical study of human capital, career mobility and employment outcomes in a mediated labour market. Human Relations, 58(8), 981-1007. doi: I0. I | 77/00 | 8726705058500

Lam, A. (2019). Hybrids, identity and knowledge boundaries: Creative artists between academic and practitioner communities. Human Relations, 73(6), 837-866. doi: 10.1 177/0018726719846259

Lamont, M. \& Molnar, V. (2002). The study of boundaries in the social sciences. Annual Review of Sociology, 28(1), 167-195. doi: 10.1 |46/annurev. soc.28.110601.141107

Lang, G. E. \& Lang, K. (1988). Recognition and renown: The survival of artistic reputation. American Journal of Sociology, 94(I), 79-109. doi: 10.1086/228952

Lang, K. \& Lang, G. E. (2002). Reputation. In N. J. Smelser \& P. B. Baltes (Eds.), International encyclopedia of the social and behavioral sciences (pp. 13210-13216). Elsevier.

Langley, A., Lindberg, K., Mørk, B. E., Nicolini, D., et al. (2019). Boundary work among groups, occupations, and organizations: From cartography to process. Academy of Management Annals, I 3(2), 704-736. http://doi. org/10.5465/annals.2017.0089

Laudel, G., Bielick, J. \& Gläser, J. (20l8). Ultimately the question always is: 'What do I have to do to do it right?' Scripts as explanatory factors of career decisions. Human Relations, 72(5), 932-961. doi: 10.1 177/ 0018726718786550

Leclair, D. (2007). René Char: là où brûle la poésie: biographie. Aden.

Lesnard, L. (2006). Optimal matching and social sciences. Documents du Crest, I, I-25.

Lips-Wiersma, M. \& Hall, D.T. (2007). Organizational career development is not dead: A case study on managing the new career during organizational change. Journal of Organizational Behavior, 28(6), 77I-792. doi: 10.1002/job.446

Lunden, R., Ekelund, B. G. \& Blom, M. B. (2002). Literary generations and social authority: A study of US prose-fiction debut writers, 1940-2000. Poetics, 30(5-6), 299-309. doi: 10.1016/S0304-422X(02)00026-8

Lupu, I. (20I2). Approved routes and alternative paths: The construction of women's careers in large accounting firms. Evidence from the French Big Four. Critical Perspectives on Accounting, 23(4-5), 35 I-369. doi: I0.1016/j.cpa.2012.01.003

Mallon, M., Duberley, J. \& Cohen, L. (2005). Careers in public sector science: Orientations and implications. R\&D Management, 35(4), 395-407. doi: |0. | | | |/j. | 467-93 |0.2005.00397.x

Maulpoix, J.-M. (200I). Frictions. In F. Smith \& C. Fauchon (Eds.), Zigzag poésie (pp. 79-85). Autrement.

McAlearney, A. S. (2006). Leadership development in healthcare: A qualitative study. Journal of Organizational Behavior, 27(7),967-982. doi: I0.1002/ job.417

McClellan, J. E. ( 1993). L'Europe des Académies. Dix-huitième Siècle, 25(I), |53-|65. doi: 10.3406/dhs. 1993.1916

Menger, P.-M. (1999). Artistic labor markets and careers. Annual Review of Sociology, 25, 54 I-574. doi: 10. I |46/annurev.soc.25. I.54 I

Menger, P.-M. (200I). Le paradoxe du musicien: le compositeur, le mélomane et l'Etat dans la société contemporaine. L'Harmattan.

Menger, P.-M. (2014). The economics of creativity. Harvard University Press.

Merton, R. K. (1968). The Matthew effect in science. Science, 159(3810), 56-63. doi: 10.1|26/science. 159.3810 .56

Moen, P. \& Orrange, R. M. (2002). Careers and lives socialization, structural lag, and gendered ambivalence. Advances in Life Course Research, 7, 23 I-260. doi: 10.10 16/S 1040-2608(02)80036-3

Mouaci, A. (200I). Les poètes amateurs: approche sociologique d'une conduite culturelle. L'Harmattan.
Moulin, R. (1994). The construction of art values. International Sociology, 9(I), 5-12. doi: I0.1 |77/02685809400900100।

Moulin, R. (2003). Le marché de l'art: mondialisation et nouvelles technologies. Flammarion.

Mounin, G. (1962). Poésie et société. PUF.

Neale, S. \& Smith, M. (20।3). Contemporary Hollywood cinema. Routledge.

Peltoniemi, M. (20I5). Cultural industries: Product-market characteristics, management challenges and industry dynamics. International Journal of Management Reviews, I 7( I), 4 I-68. doi: I0. I I I //jimr. I 2036

Petit, Y. (20।2). Book review. In G. Cattani, S. Ferriani, L. Frederiksen \& F. Täube (Eds.) (20ll) Project-based organizing and strategic management.M@n@gement, 15(3),333-342.doi: 10.3917/mana.153.0333.

Pleij, H. (2002). Restyling 'wisdom,' remodeling the nobility, and caricaturing the peasant: Urban literature in the late medieval low countries. Journal of Interdisciplinary History, 32(4), 689-704. doi: I 0. I | 62/0022 195023 | 7345565

Pouly, M.-P. (2016). Playing both sides of the field:The anatomy of a 'quality' bestseller. Poetics, 59, 20-34. doi: 10.10 16/j.poetic.2016.02.002.

Preece, C. \& Kerrigan, F. (20 I5). Multi-stakeholder brand narratives: An analysis of the construction of artistic brands. Journal of Marketing Management, 3 | ( | - |2), | 207-1230. doi: |0. I080/0267257X.20 | 4.997272

Preisig, F. (2007). Le poète de cour: condition sociale et représentation de soi chez Marot et Ronsard. Travaux de littérature, 20, 75-88.

Quick, K. S. \& Feldman, M. S. (2014). Boundaries as junctures: Collaborative boundary work for building efficient resilience. Journal of PublicAdministration Research and Theory, 24(3), 673-695. doi: 10.1093/jopart/mut085

Rigolot, F. (2002). Poésie et Renaissance (Vol. 486). Seuil.

Rodrigues, R. \& Guest, D. (20|4a). Beyond the duality between bounded and boundaryless careers: New avenues for careers research. Career Development International, 19(6). doi: I0. I I08/CDI-09-2014-0123

Rodrigues, R. \& Guest, D. (20|4b). Bounded, boundaryless or both? An empirical exploration of the link between perception of boundary strength and mobility across multiple career domains. International Congress of Applied Psychology, Paris, France.

Rodrigues, R., Guest, D. \& Budjanovcanin, A. (20|6). Bounded or boundaryless? An empirical investigation of career boundaries and boundary crossing. Work, Employment \& Society, 30(4), 669-686. doi: 10.1 177/09 50017015570726

Rodrigues, R. A. \& Guest, D. (2010). Have careers become boundaryless? Human Relations, 63(8), I I57-I |75. doi: I0. I I77/00 I 8726709354344

Rosengren, K. E. ( 1 985). Time and literary fame. Poetics, I 4(I-2), I57-I 72. doi: $10.1016 / 0304-422 \times(85) 90009-9$

Roubaud, J. (1978). La vieillesse d'Alexandre. Maspéro.

Roubaud, J. (1995). Poésie, etcetera, ménage. Stock.

Sapiro, G. (1998). La guerre des écrivains (1940-1953). Fayard.

Sapiro, G. (2003). The literary field between the state and the market. Poetics, 3 I (5-6), 44 I-464. doi: I0. I 0 I6/j.poetic.2003.09.00 I

Sapiro, G. (2016). The metamorphosis of modes of consecration in the literary field: Academies, literary prizes, festivals. Poetics, 59, 5-19. doi: 10.1016/j.poetic.2016.01.003

Sapiro, G. (2019). The writing profession in France: Between symbolic and professional recognition. French Cultural Studies, 30(2), 105-120. doi: | 0.1 |77/0957|558|9844|55

Schworm, S. K., Cadin, L., Carbone, V., Festing, M., Leon, E., \& MuratbekovaTouron, M. (2017). The impact of international business education on career success-Evidence from Europe. European Management Journal, 35(4), 493-504. doi: 10. I0 I6/j.emj.2017.02.009

Sgourev, S. V. (2013). How Paris gave rise to Cubism (and Picasso): Ambiguity and fragmentation in radical innovation. Organization Science, 24(6), I60 I-16 17. doi: 10.1287/orsc. I |20.0819 
Simonin, A. (1998). L'édition littéraire. In P. Fouché (Ed.), L'édition depuis 1945 (pp. 30-87). Cercle de la Librairie.

Spiro, J. (2004). Creative poetry writing. Oxford University Press.

Staniland, N. A., Harris, C. \& Pringle, J. K. (2019). Indigenous and boundaryless careers: Cultural boundaries in the careers of Māori academics. The International Journal of Human Resource Management, I-20. doi: I0. 108 0/09585192.2019.1651377.

Stéfan, J. (2005). Rencontre avec Tristan Hordé. Paris: Argol.

Stjerne, I. S. \& Svejenova, S. (2016). Connecting temporary and permanent organizing: Tensions and boundary work in sequential film projects. Organization Studies, 37(I2) |77 | - |792. doi: I 0. I | 77/0 | 708406 | 6655492

Storper, M. (1989). The transition to flexible specialization in the US film industry, external economies, the division of labour and the crossing of industrial divides. Cambridge Journal of Economics, 13(2), 273-305. doi: 10.1093/oxfordjournals.cje.a035094

Thompson, M. J. (20I5). False consciousness reconsidered: A theory of defective social cognition. Critical Sociology, 4 I (3), 449-46 I. doi: I 0.1 I 77 I $08969205|45288| 7$

Tilly, C. \& Tarrow, S. (2006). Contentious politics. Paradigm.

Vaillant, A. (2017). L'histoire littéraire. Armand Colin.

Verboord, M. (20I I). Market logic and cultural consecration in French, German and American bestseller lists, 1970-2007. Poetics, 39(4), 290-3 15. doi: I0.1 01 6/j.poetic.20 I 1.05.002

Vercier, B. \& Viart, D. (2005). La littérature française au présent. Bordas.
Viala, A. (1985). Naissance de l'écrivain: sociologie de la littérature à l'âge classique. Editions de Minuit.

Weber, M. (1978). Economy and society. An outline of interpretive sociology. University of California Press.

White, C. \& White, H. C. (1992). Canvases and careers. Institutional change in the French painting world. University of Chicago Press.

Wijnberg, N. M. \& Gemser, G. (2000). Adding value to innovation: Impressionism and the transformation of the selection system in visual arts. Organization Science, I I (3), 323-329. doi: I0. I287/orsc. I I. 3.323. 12499

Wilensky, H. L. (196I). Orderly careers and social participation:The impact of work history on social integration in the middle mass. American Sociological Review, 26(4), 52 I-539. doi: | 0.2307/209025 |

Zhao, W. \& Zhou, X. (20I3). Intraorganizational career advancement and voluntary turnover in a multinational bank in Taiwan. Career Development International, I 3(5), 402-424. doi: I 0. I 108/I 36204308 I 089 | 446

Zwaan, K., ter Bogt, T. F. M. \& Raaijmakers, Q. (20 I0). Career trajectories of Dutch pop musicians: A longitudinal study. Journal of Vocational Behavior, 77(I), I0-20. doi: I0.10 I6/j.jvb.20 I0.03.004

\section{Appendices I-2}

